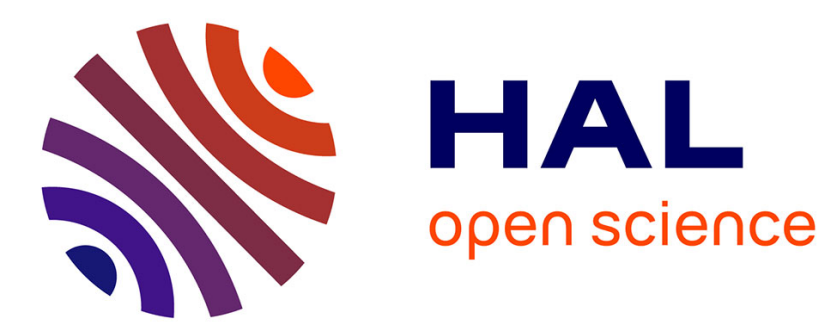

\title{
Oxide-supported PtCo alloy catalyst for intermediate temperature polymer electrolyte fuel cells
}

Alessandro Stassi, Irene Gatto, Vincenzo Baglio, Enza Passalacqua, Antonino Arico'

\section{- To cite this version:}

Alessandro Stassi, Irene Gatto, Vincenzo Baglio, Enza Passalacqua, Antonino Arico'. Oxide-supported PtCo alloy catalyst for intermediate temperature polymer electrolyte fuel cells. Applied Catalysis B: Environmental, 2013, pp.15-24. 10.1016/j.apcatb.2013.05.008 . hal-00904834

\section{HAL Id: hal-00904834 https://hal.science/hal-00904834}

Submitted on 15 Nov 2013

HAL is a multi-disciplinary open access archive for the deposit and dissemination of scientific research documents, whether they are published or not. The documents may come from teaching and research institutions in France or abroad, or from public or private research centers.
L'archive ouverte pluridisciplinaire HAL, est destinée au dépôt et à la diffusion de documents scientifiques de niveau recherche, publiés ou non, émanant des établissements d'enseignement et de recherche français ou étrangers, des laboratoires publics ou privés. 


\title{
Oxide-supported PtCo alloy catalyst for intermediate temperature polymer
}

\section{electrolyte fuel cells}

\author{
Alessandro Stassi, Irene Gatto, Vincenzo Baglio, Enza Passalacqua, Antonino S. Aricò * \\ CNR-ITAE Istituto di Tecnologie Avanzate per l'Energia "Nicola Giordano"
}

Via Salita S. Lucia sopra Contesse 5, 98126 Messina, Italy

\begin{abstract}
A Pt-Co alloy catalyst supported on a Ta-doped Ti-oxide was investigated for the oxygen reduction reaction in a polymer electrolyte fuel cell (PEMFC) operating between $80^{\circ}$ and $110{ }^{\circ} \mathrm{C}$ at different relative humidity (100\% and 33\% R.H.). A crystalline Anatase phase was obtained for the Ta-doped Ti-oxide support with BET surface area of about $150 \mathrm{~m}^{2} / \mathrm{g}$. $\mathrm{Pt}$ and $\mathrm{Pt}_{3} \mathrm{Co}_{1}$ nanoparticles dispersed on the Ta-doped Ti-oxide showed a crystallite size of 3.9 and $2.9 \mathrm{~nm}$, respectively. These catalysts were investigated in PEMFC and benchmarked against a carbon supported $\mathrm{Pt}_{3} \mathrm{Co}_{1}$ of similar crystallite size $\left(\mathrm{Pt}_{3} \mathrm{Co}_{1} / \mathrm{C}\right)$. Under automotive relevant operating conditions, i.e. at intermediate temperatures $\left(110{ }^{\circ} \mathrm{C}\right)$, and in the presence of low relative humidity (33\% R.H.), the oxidesupported PtCo was approaching in performance the $\mathrm{Pt}_{3} \mathrm{Co}_{1} / \mathrm{C}$ catalyst. The performance of PtCo/oxide was better than that of Pt/oxide under all operating conditions. The oxide supported PtCo catalyst showed a lower electrochemically active surface area (ECSA) and larger ohmic resistance with respect to the $\mathrm{Pt}_{3} \mathrm{Co}_{1} / \mathrm{C}$. On the other hand, the oxide-supported catalysts appeared stable during an accelerated corrosion test at $1.4 \mathrm{~V}$ RHE while a dramatic decrease of the ECSA was observed for the $\mathrm{Pt}_{3} \mathrm{Co}_{1} / \mathrm{C}$ under the same condition. Thus, the oxide supported PtCo alloy catalyst appears promising in terms of electrochemical stability and for automotive applications.
\end{abstract}

Key-words: Pt catalysts, Fuel cells, Oxygen reduction reaction, Doped Ti-oxide support, Intermediate temperature.

\footnotetext{
* Corresponding author. Tel.: +39 090624237; fax: +39 090624247. E-mail address: arico@itae.cnr.it (A.S. Aricò).
} 


\section{Introduction}

The catalyst support plays an important role for fuel cell electro-catalysts [1]. A high utilization of noble metal active phase, usually Pt, is achieved by dispersing nanosized electrocatalyst particles on a high surface area conducting support [1]. The support provides a physical surface for the dispersion of the active phase; this is necessary for achieving high electrochemically active surface area as required to increase the number of catalytic sites involved in the fuel cell reactions [2]. A synergistic role of the support in terms of performance and stability can be played through catalystsupport interaction [1]. Beside the high surface area, high electrical conductivity, suitable mesoporous morphology, suitable resistance to chemical and electrochemical corrosion are the properties required to a catalyst support for application in fuel cells [2]. Carbon black supports such as Vulcan XC and Ketjenblack EC are the primary choice since they combine proper morphology, high electronic conductivity and good capability of enhancing the dispersion of the active phase $[1,3]$. Yet, an important requisite for the support, i.e. the electrochemical stability, is not completely fulfilled by this class of materials causing relevant constraints especially when high electrochemical potentials occur during cycled operation, during OCV transients and under fuel starvation conditions [3]. All these conditions are relevant for the automotive applications since they affect the life-time of the fuel cell stack [3]. Typical degradation phenomena affecting carbon-supported fuel cell catalysts regard Pt dissolution and re-precipitation, particle growth, increase of agglomeration of Pt nanoparticles, occurrence of electrically isolated Pt particles due to dissolution and reprecipitation in the membrane $[4,5,6]$. These effects reduce the durability of the cathode catalysts with severe consequences on the reliability of the entire fuel cell system.

Alternative supporting materials such as tungsten oxide or carbide, $\mathrm{Ti}$ or $\mathrm{Sn}$ oxides and $\mathrm{Ti}$ borides or nitrides are chemically and electrochemically stable in an acidic environment and may represent interesting classes of catalyst supports for PEMFCs [7-17]. Conductive sub-oxides of titanium, such as Ebonex ${ }^{\circledR}$ characterised by a Magneli phase (e.g. $\mathrm{Ti}_{4} \mathrm{O}_{7}$ ), have been extensively studied [7,8,18-20]. Unfortunately, most of these sub-oxides supports are characterised by low 
surface area due to the high temperature $\left(>1000{ }^{\circ} \mathrm{C}\right)$ of the reduction treatment which makes difficult an effective dispersion of the active catalytic phase. The surface area of commercial Tisuboxides (Ebonex ${ }^{\circledR}$ ) is around $2 \mathrm{~m}^{2} / \mathrm{g}$ [21], whereas it must be at least two orders of magnitude larger to allow for a good dispersion of the active phase. Proper chemical routes appear necessary to prepare $\mathrm{Ti}$ sub-oxides and doped $\mathrm{Ti}$-oxides with large surface area and optimal electronic conductivity. Ti-suboxide or doped Ti-oxide supports may stabilise the Pt active phase through a strong catalyst-support interaction [2,22]. This could reduce the electrochemical degradation of $\mathrm{Pt}$, e.g. dissolution, agglomeration and particle growth, which in conventional $\mathrm{Pt} / \mathrm{C}$ catalysts is promoted by the corrosion of the carbon support [4-6].

At the present, several approaches are actively pursued to enhance the stability of cathode electro-catalysts in PEMFCs. The most used approach is concerning with the development of highly graphitic carbon supports including graphitized carbons, carbon nanotubes, nanofibers, graphene etc. [2]. A highly graphitic character appears a pre-requisite to increase the resistance to corrosion. The electrochemical corrosion is relevant especially for amorphous carbons [23]. However, a high surface area in a carbon support is often associated to the occurrence of amorphous carbon [1]. Another approach regards the formation of a composite of $\mathrm{TiO}_{2}$ and carbon black or other carbonaceous materials such as carbon nanotubes [24-29]. $\mathrm{TiO}_{2}$ provides a stable support whereas the carbon component increases the electronic percolation. Although, some improvement has been recorded using this approach, the Pt stability under electrochemical operation appears only moderately improved. The carbon support in the composite material is electrochemically corroded and its positive effect in terms of enhancement of conduction and dispersion is progressively lost. As above mentioned, PEMFC stability can be enhanced by using Ti-suboxide supported catalysts $[7,8,18-20]$. The main drawback is a low dispersion due to the modest surface area of Magneliphase materials. A progressive transformation of sub-oxides into a more stable stoichiometric titania phase has been also postulated [30]. However, it is worth noting that these materials find application in electrolysers operating in a potential window much wider than that of a fuel cell. 
$\mathrm{TiO}_{2}$ may be prepared with a suitable surface area to achieve proper dispersion of the active phase and with mesoporous structure [31,32]; moreover, it is an electrochemically stable material in acid environment but, due to its semiconducting properties, the electronic conductivity is modest. This problem has been addressed by enhancing the electronic percolation through the surface using a large concentration of metal phase on the support and/or using nanosized particles for the support [32]. Interesting performances and electrocatalytic activities have been reported in the literature for $\mathrm{Pt} / \mathrm{TiO}_{2}$ catalysts $[31,32]$. However, it appears that an enhancement of electronic conductivity for the support can be achieved by doping $\mathrm{TiO}_{2}$ with $\mathrm{Nb}$ or $\mathrm{Ta}[22,33,34]$. This corresponds to an increase of performance for $\mathrm{Pt}$ fuel cell catalysts supported on a doped $\mathrm{TiO}_{2}$ compared to similar catalysts supported on bare titania. The doped supports enhance the electronic percolation through the bulk. As an example, $\mathrm{Nb}$-doping causes the occurrence of $\mathrm{Ti}^{3+}$ species to compensate in terms of electro-neutrality for the presence of $\mathrm{Nb}^{5+}$ species. The $\mathrm{Ti}^{3+}$ species introduce electronic levels in the titania band gap which are responsible for the increased electronic conductivity as in the Magneli phase [35]. A $\mathrm{TiO}_{2}$ highly doped e.g. a $\mathrm{Ti}_{0.75} \mathrm{Ta}_{0.25} \mathrm{O}_{2}$ has only a slightly different nominal fraction of $\mathrm{Ti}^{3+}$ species than $\mathrm{Ti}_{4} \mathrm{O}_{7}$ but the first can retain the Anatase structure whereas in the latter the sub-stoichiometry is not stabilized by effect of electroneutrality. Thus, in principle, the doped $\mathrm{Ti}$ oxide should be more stable than the sub-stoichiometric Ti oxide; however, Ebonex-type materials generally possess higher electronic conductivities than doped Ti-oxides [27, 35].

As above discussed the choice of a support material is governed by conductivity, BET surface area, mesoporous structure and intrinsic electrochemical stability. Our efforts have been addressed to the investigation of $\mathrm{Ti}_{0.75} \mathrm{Ta}_{0.25} \mathrm{O}_{2}$ as support because this material should, in principle, be characterised by the best compromise with regard to these relevant properties. In general, most of the research reports in the literature concerning with these novel oxide or doped-oxide supports deal with pure Pt or non-precious electrocatalysts while limited efforts have been addressed to Pt-alloys [36]. The electrocatalytic activity and the performance achieved with these new materials is generally benchmarked against conventional Pt/C catalysts. However, in recent years, significant 
efforts have been carried out to develop carbon supported Pt-alloys $[3,37,38]$. Today, these better represent the state of the art of ORR catalysts in fuel cells. Accordingly, the aim of this work is to address the development of a $\mathrm{Pt}_{3} \mathrm{Co}_{1}$ alloys catalyst supported on $\mathrm{Ti}_{0.75} \mathrm{Ta}_{0.25} \mathrm{O}_{2}$. We have thus compared the electrocatalytic activity of the novel catalyst with respect to a $\mathrm{Pt}_{3} \mathrm{Co}_{1}$ alloy supported on a carbon black $\left(\mathrm{Pt}_{3} \mathrm{Co}_{1} / \mathrm{C}\right)$ and characterised by a similar crystallite size $\sim 3 \mathrm{~nm}$. In a previous work, we have observed that both the catalytic activity and the stability of carbon supported $\mathrm{Pt}_{3} \mathrm{Co}_{1}$ alloy catalysts were superior than a $\mathrm{Pt} / \mathrm{C}$ catalyst of similar particle size [38]. Several recent reports in the literature have shown that $\mathrm{Pt}_{3} \mathrm{Co}_{1} / \mathrm{C}$ catalysts are among the most performing cathode materials in fuel cells $[3,37]$. Thus, we think that $\mathrm{PtCo} / \mathrm{C}$ may represent a proper reference to compare performance and stability of the catalysts based on a novel support. We have also investigated the performance of the oxide supported alloy with respect to a Pt catalyst dispersed on the same oxide support material.

Recently, significant efforts have been addressed to investigate catalyst activity for intermediate temperature operation (e.g. $110^{\circ}-130{ }^{\circ} \mathrm{C}$ ) that is more relevant for automotive applications $[39,40]$. It is known that an intermediate operating temperature allows a better thermal and water management. This may allow for a simplification of the fuel cell system with a strong impact on volume, costs and reliability [39]. In the absence of a benchmark membrane for these operating conditions, we have preferred to work with a conventional Nafion membrane under pressurised mode thus avoiding the complete membrane dehydration above $100{ }^{\circ} \mathrm{C}[38,40]$. The oxide supported PtCo-alloy shows interesting catalytic activities and stability for intermediate temperature operation.

\section{Experimental}

\section{$2.1 \mathrm{Ti}_{0.75} \mathrm{Ta}_{0.25} \mathrm{O}_{2}$ support preparation}

$\mathrm{Ti}$ and $\mathrm{Ta}$ sulphite complexes were prepared by reaction of $\mathrm{Ti}$ and $\mathrm{Ta}$ chloride salts $\left(\mathrm{TiCl}_{4}\right.$ and $\mathrm{TaCl}_{5}$ ) with sodium dithionite. These complexes were mixed in proper amounts in an acidic 
solution to achieve an atomic ratio $\mathrm{Ti} / \mathrm{Ta}=3: 1$ in the final oxide support. The complexes were decomposed in the presence of $\mathrm{H}_{2} \mathrm{O}_{2}$ to form a colloidal suspension. This gives rise to an amorphous oxide after flocculation. The obtained amorphous doped Ti-oxides were thermally activated at various temperatures in the range $300^{\circ}-600{ }^{\circ} \mathrm{C}$ and analysed in terms of surface area and crystalline properties. The temperature of $400{ }^{\circ} \mathrm{C}$ was thereafter selected for the thermal treatment of the doped-support used for catalyst preparation since this resulted in a proper compromise between suitable surface area $\left(150 \mathrm{~m}^{2} / \mathrm{g}\right)$ and structural properties. Undoped $\mathrm{TiO}_{2}$ was prepared in the same way (Supplementary Material section).

\subsection{Catalyst preparation}

Electro-catalysts consisted of $\mathrm{Pt}$ or $\mathrm{Pt}_{3} \mathrm{Co}_{1}$ alloy supported on $\mathrm{Ti}_{0.75} \mathrm{Ta}_{0.25} \mathrm{O}_{2}$ or on a carbon black. The total metal fraction on the doped-oxide support was $40 \% \mathrm{wt}$. This level of metal concentration was selected as compromise between dispersion and coverage of support by metal particles to favour the electronic percolation. A similar catalyst based on undoped $\mathrm{TiO}_{2}$ support with $\mathrm{Pt} 40 \%$ wt. content has not given suitable activity results for the oxygen reduction due to some electronic conductivity constraints (see Supplementary Material section).

A Pt-sulphite complex was prepared by reaction of $\mathrm{H}_{2} \mathrm{PtCl}_{6}$ with sodium dithionite. The Ptsulphite salt was first dissolved in acidic solution and subsequently decomposed with $\mathrm{H}_{2} \mathrm{O}_{2}$ to form a colloidal dispersion that was impregnated on the $\mathrm{Ti}_{0.75} \mathrm{Ta}_{0.25} \mathrm{O}_{2}$ support. Co was thus deposited by incipient wetness of cobalt nitrate on the amorphous PtOx phase previously obtained on the dopedoxide support. The concentration of $\mathrm{Co}\left(\mathrm{NO}_{3}\right)_{2}$ was adjusted to achieve a Pt/Co atomic ratio of 3:1 in the final catalyst. The as-formed catalyst was thus thermally treated in $\mathrm{H}_{2}$ atmosphere at $150{ }^{\circ} \mathrm{C}$ to form PtCo alloy nanoparticles. For comparison, a $\mathrm{Pt} / \mathrm{Ti}_{0.75} \mathrm{Ta}_{0.25} \mathrm{O}_{2}$ catalyst was prepared by the same procedure. Whereas the $\mathrm{Pt}_{3} \mathrm{Co}_{1} / \mathrm{C}$ catalyst consisted of a Ketjenbalck EC support $\left(850 \mathrm{~m}^{2} / \mathrm{g}\right)$. A similar procedure was used; but, regarding the final reduction treatment, a carbothermal treatment at $600{ }^{\circ} \mathrm{C}$, instead of the reduction in a hydrogen stream, was carried out. The carbothermal method has permitted a better modulation of the crystallite size for the carbon black support-based catalyst 
allowing to achieve the same crystallite size of the $\mathrm{PtCo} /$ oxide catalyst. Both cathode catalysts were pre-leached in $\mathrm{HClO}_{4} 0.1 \mathrm{M}$ at $80{ }^{\circ} \mathrm{C}$ before use.

A $30 \% \mathrm{Pt} /$ Vulcan $\mathrm{XC}-72 \mathrm{R}$ catalyst obtained by a similar procedure was used as anode in the PEMFC.

\subsection{Physico-Chemical Analysis}

Both supports and catalysts were characterised by X-ray diffraction (XRD) using a Philips Xpert diffractometer with $\mathrm{Cu} \mathrm{Ka}$ radiation. The peak profile of the (220) reflection in the face centered cubic structure of Pt and Pt-alloys was used to calculate the metal crystallite size by the Debye-Scherrer equation [38]. An X-ray fluorescence analysis was carried out by using a Bruker AXS S4 Explorer spectrometer. In the carbon supported material used as reference, the total metal content was determined by burning the carbon support in a thermal gravimetry experiment at 950 ${ }^{\circ} \mathrm{C}$ in air. Transmission electron microscopy (TEM) analysis was carried out with a FEI CM12 microscope. The surface area of the support was determined by BET analysis. X-ray photoelectron spectroscopy (XPS) measurements were performed by using a Physical Electronics (PHI) 5800-01

spectrometer with monochromatic Al Ka X-ray source. Thermal analysis of the doped-oxide support was carried out through thermal gravimetry (TG) and differential scanning calorimetry (DSC) at $5^{\circ} \mathrm{C} / \mathrm{min}$ by using a Netzsch thermal analyser.

Experimental details for physico-chemical analysis are provided in the Supplementary Material section.

\subsection{Electrochemical Studies}

The electrodes were prepared according to the procedure described in a previous report [37]. The catalytic layer was composed of 33 wt.\% Nafion ionomer (1100 g/eq.) and 67 wt.\% catalyst. In all experiments, the Pt loading was $0.3 \mathrm{mg} \mathrm{cm}^{-2}$ at both electrodes. MEAs were formed by a hotpressing procedure. A Nafion 115 membrane $(\sim 120 \mu \mathrm{m})$ was used in order to reduce the effect of $\mathrm{H}_{2}$ cross-over, to allow for a proper determination of the mass activity at $0.9 \mathrm{~V}$ RHE. 
Steady-state galvanostatic polarization experiments in PEMFC were performed in the presence of $\mathrm{H}_{2}-\mathrm{O}_{2}$ at various temperatures and R.H. under pressurised conditions ( 3 bar abs) to avoid Nafion membrane dehydration above $80^{\circ} \mathrm{C}$. Electrochemical data were not corrected for gas cross-over. Cyclic voltammetry (CV) studies were carried out at $80{ }^{\circ} \mathrm{C}$. Electrochemical active surface active area (ECSA) was determined from the integration of the hydrogen adsorption region, after correction for the double layer capacitance at $0.4 \mathrm{~V}$ and assuming that a charge of $210 \mu \mathrm{C} \mathrm{cm}^{-2}$ of real surface area was involved in the adsorption process. Accelerated stress tests (AST) were carried out under half-cell conditions in the presence of sulphuric acid electrolyte $(0.5 \mathrm{M})$ by potential holding at $1.4 \mathrm{~V}$ RHE in the presence of $\mathrm{N}_{2}$ feed. A Ti grid as backing layer and current collector was used in these experiments. High electrochemical potentials occur in a fuel cell in the presence of a local fuel starvation or reverse current conditions $[2,3,41,42]$. These represent the most critical situations which occur in a fuel cell affecting catalyst stability. In general, a driven electrode operation at $1.4 \mathrm{~V}$ RHE represents a relevant stress test providing, on a short time scale, information about degradation effects which are typical of long term fuel cell operation under normal conditions [3]. After the electrochemical stress test, the cathode layer was detached and exsitu characterized by electron microscopy.

The conduction properties of the support materials in the form of loose powders, as conventionally used in fuel cell electrodes, was determined in half cell from the difference between the electrode series resistance recorded in the presence and absence of the support material on the electrode backing layer.

Experimental details for the electrochemical studies are provided in the Supplementary Material section.

\section{Results and discussion}

\subsection{Ex-situ physico-chemical studies}


The structure and morphology of the $\mathrm{Ti}_{0.75} \mathrm{Ta}_{0.25} \mathrm{O}_{2}$ support was studied by using X-ray diffraction and transmission electron microscopy (Fig. 1) whereas the Ti/Ta ratio was determined by X-ray fluorescence. The XRF results have essentially confirmed the nominal composition. Fig. 1 shows the XRD patterns of the support revealing mainly the presence of an Anatase phase. An amorphous halo in the $2 \theta$ range $20-40^{\circ}$ indicates that there is no complete conversion of the precursor amorphous colloidal oxide into Anatase at $400{ }^{\circ} \mathrm{C}$. However, this mixed amorphouscrystalline structure is analogous of that of carbon blacks, such as the Ketjenblack carbon used here for comparison. In most of the carbon blacks used in fuel cells, graphitic basal planes $\left(\mathrm{sp}^{2}\right)$ are present in conjunction with amorphous carbon $\left(\mathrm{sp}^{3}\right)[1,2]$. This mixed structure can favour the dispersion of the metal phase. No relevant occurrence of chloride or sulphur impurities from the precursors has been observed in this material from XRF. The TEM analysis showed the presence of a mesoporous structure and particle sizes in the range $10-20 \mathrm{~nm}$ for the oxide support (Fig. 1 inset) in agreement with the measured BET surface area of $150 \mathrm{~m}^{2} / \mathrm{g}$.

XRD analysis of the catalyst powders (Fig. 2) showed that both carbon and oxide-supported catalysts were characterised by a $\mathrm{Pt}$ or a $\mathrm{Pt}_{3} \mathrm{Co}_{1}$ disordered face centered cubic structure (fcc) related to the $(F m \overline{3} m)$ space group (JCPDS card 04-0802). Peaks corresponding to the main reflections of the hexagonal structure of carbon black (002) and Anatase structure of the oxide support were also observed (Fig. 2). A shift of the diffraction peaks to higher Bragg angles for the face centered cubic phase in the PtCo catalysts with respect to a pure Pt phase was evident (Fig. 2). This confirmed the occurrence of a Pt-Co metal alloy. Mean crystallite size, lattice parameter, atomic ratio in the true alloy or degree of alloying, as derived from the analysis of 220 reflection in Pt or PtCo structure are reported in Table 1. Line broadening analysis of the 220 reflection (Fig. 2) indicated a crystallite size of $2.9 \mathrm{~nm}$ for the carbon supported PtCo alloy whereas this was $2.9 \mathrm{~nm}$ and $3.9 \mathrm{~nm}$ in the oxide supported PtCo and Pt catalysts. For both PtCo catalysts, a large lattice $\left(A_{220}\right)$ contraction compared to the Pt catalyst $\left(A_{220}=0.392\right)$ corresponding to a specific degree of alloying has been observed (Table 1). The Pt/Co atomic ratio in the alloy, as determined by XRD, 
was about 4.4 and 3.2 in the samples based on oxide and carbon supports, respectively. These values were close to the nominal ratio and essentially similar to the atomic $\mathrm{Pt} / \mathrm{Co}$ ratios obtained from XRF. However, the degree of alloying was slightly lower in the oxide-supported PtCo catalyst compared to the carbon supported one. This could be due to the different thermal treatment experienced by these catalysts (reduction in hydrogen at $150{ }^{\circ} \mathrm{C}$ for the oxide-supported catalyst vs. carbothermal treatment at $600{ }^{\circ} \mathrm{C}$ for the carbon black supported catalyst). Such different thermal treatments were selected to obtain the same crystallite size for the $\mathrm{Pt}_{3} \mathrm{Co}_{1}$ phase in both materials as necessary to compare the different electrocatalytic activities as a function of the support.

TEM analysis (Fig. 3) has shown excellent dispersion for the carbon supported PtCo catalyst. Whereas, lower dispersion was observed for the oxide supported catalysts. The moderate surface area of the oxide support $\left(150 \mathrm{~m}^{2} / \mathrm{g}\right.$ vs. $850 \mathrm{~m}^{2} / \mathrm{g}$ for the Ketjenblack carbon) caused the occurrence of densely packed particles with very small inter-particle distance. A different level of interaction between metal particle and support surface for the oxide and carbon black may be also responsible of the particle agglomeration in the oxide-based catalyst. However, a good coverage of the oxide support particles by the metal phase was observed. This is appropriate in order to favour the electronic percolation on the surface in the presence of a less conductive but electrochemically stable support [43]. A drawback of this approach sometime concerns with a reduced of $\mathrm{Pt}$ utilization. The dimensions of metal particles in the TEM micrographs $(4-5 \mathrm{~nm})$ were slightly larger than the size of crystallite domains derived from XRD.

X-ray photoelectron survey spectra of the PtCo/oxide and $\mathrm{PtCo} / \mathrm{C}$ catalysts are shown in Fig. 4. The typical Auger and photoelectron lines of $\mathrm{Pt}, \mathrm{Co}, \mathrm{C}$ and $\mathrm{O}$ were observed in the first sample whereas the second sample also showed similar lines for $\mathrm{Ti}$ and Ta. There was no significant evidence of impurities. An intense Pt4f signal was observed for the PtCo/oxide catalyst indicating a large coverage of the oxide support surface by $\mathrm{Pt}$ metal particles. Whereas, in the $\mathrm{PtCo} / \mathrm{C}$ catalyst the carbon signal deriving from both carbon support and adventitious carbon was prevailing. 
By comparing the Pt4f and Co2p photoelectron lines and their sensitivity factors, it was possible to estimate the $\mathrm{Pt} / \mathrm{Co}$ atomic ratio. This was about 5 in both catalysts. Thus, a clear enrichment of Pt on the surface for both samples was present. This was probably caused by the preleaching procedure in acid. The surface $\mathrm{Ti} / \mathrm{Ta}$ atomic ratio was about 4 in agreement with the nominal value for the bulk. After deconvolution of the high resolution Pt $4 \mathrm{f}$ spectra for both $\mathrm{PtCo} /$ oxide and $\mathrm{PtCo} / \mathrm{C}$ samples (Fig. 5), it was observed that in both cases there was a large prevalence of metallic $\mathrm{Pt}$ with a small fraction of $\mathrm{Pt}^{2+}$ species that reached an amount of $10 \%$ in the PtCo/oxide catalyst.

It is derived from the XPS analysis that some surface characteristics relevant for the ORR, such as Pt oxidation state and Pt/Co ratio on the surface, are essentially similar in these catalysts.

XPS data of the Ta-doped $\mathrm{Ti}$ oxide support in the alloy catalyst are reported in the Supplementary Material section (Fig S1). The analysis of the $\mathrm{Ti} 2 \mathrm{p}_{3 / 2}$ region has indicated that $\mathrm{Ti}$ was mainly present on the surface as Anatase $\mathrm{Ti}^{4+}$ species $(91 \%)$ with a modest content of substoichiometric $\mathrm{Ti}^{3+}$ species $(9 \%)$. The latter was much lower than the amount expected from electroneutrality considerations. However, such evidence does not exclude the presence of a larger amount of $\mathrm{Ti}^{3+}$ species in the bulk. The analytical XPS region of Tantalum (Ta4f) showed a strong overlapping with the O2s signal (Fig. S2). This did not allow to quantify the oxidation states for Ta. The main peak of the Ta $4 \mathrm{f}$ doublet has occurred at a B.E. of about $26.3 \mathrm{eV}$ which corresponded to the $\mathrm{Ta}_{2} \mathrm{O}_{5}$ specie.

The series resistance measured in half cell for the supports in the form of loose powders (no compression other than that used for the electrode lamination) was significantly higher for the doped oxide than the carbon black (0.4 vs. $\left.0.05 \mathrm{Ohm} \mathrm{cm}^{2} \mathrm{mg}^{-1}\right)$.

\subsection{Electrochemical studies}

The performance of the three cathode catalysts for the oxygen reduction reaction was investigated in-situ in a membrane-electrode assembly using the same $\mathrm{Pt} / \mathrm{C}$ anode. The anode was fed with hydrogen and, being only moderately polarised (few $\mathrm{mV}$ ) at low current densities (ORR 
mass activities for the cathode were recorded at $0.9 \mathrm{~V}$ RHE), it could be considered both as reference and counter electrode. This approach was also useful for the high current density region since it allowed a direct comparison of ohmic and mass transfer properties for the three electrocatalysts under investigation. Fuel cell polarization curves at $80{ }^{\circ} \mathrm{C}$ and full humidification are reported in Fig. 6 for the cathode catalysts under study. Under these conditions, it is clearly observed that the $\mathrm{PtCo} / \mathrm{C}$ catalyst performs better than the oxide-supported alloy. Whereas, the $\mathrm{PtCo} /$ oxide shows both superior electrocatalytic activity and higher performance than the Pt/oxide catalyst. Beside a lower electrocatalytic activity, further polarization constraints at relevant current densities are observed for the oxide-supported catalysts. A larger slope at intermediate current densities for the oxide-supported catalysts is indicative of a larger ohmic drop caused by the semiconducting properties of the Ta-doped $\mathrm{Ti}$ oxide. This reveals that, despite the aim to cover a good fraction of the oxide surface with metal particles, part of the electronic percolation in the present catalysts occurs through the bulk. Mass transport constraints at high current densities for Pt and $\mathrm{PtCo} /$ oxide catalysts possibly derive by the fact that the oxide support affects the hydrophobicity of the catalytic layer causing flooding of the cathode at high current density under low temperature and high relative humidity $\left(80^{\circ} \mathrm{C}, 100 \%\right.$ R.H.) operating conditions.

To get more information onto these aspects, ac-impedance spectra for the various catalysts were carried out at $0.7 \mathrm{~V}$ (a cell potential of practical interest) at $80{ }^{\circ} \mathrm{C}$ and $100 \%$ R.H. (Fig. 7). The cell made of the carbon supported PtCo catalyst has shown similar values of series and polarization resistances, about $0.1 \mathrm{Ohm}^{2}$. The series resistance was $0.18 \mathrm{Ohm} \mathrm{cm}^{2}$ for both oxide supported catalysts; this indicated that some ohmic polarization constraints were due to the semiconducting support; the polarization resistances were 0.32 and $0.6 \mathrm{Ohm}^{2}$ for the oxide supported PtCo-alloy and Pt electrocatalysts, respectively.

On a quantitative basis, the polarization losses for the $\mathrm{PtCo} / \mathrm{oxide}$ vs. the $\mathrm{PtCo} / \mathrm{C}$ catalyst are about twice of the electronic percolation losses. This suggests than an improvement of the $\mathrm{PtCo} /$ oxide catalyst morphology is more urgent than the improvement of the support conductivity. 
In the polarization curves of Fig. 6 , at $1 \mathrm{~A} \mathrm{~cm}^{-2}$ (a current density of practical interest), the potential loss, passing from $\mathrm{PtCo} / \mathrm{C}$ to $\mathrm{PtCo} /$ oxide catalyst, is about $200 \mathrm{mV}$ and even larger for the $\mathrm{Pt} / \mathrm{oxide}$ catalyst. From the ac-impedance spectra, we can derive that, at $1 \mathrm{~A} \mathrm{~cm}^{-2}$, a potential loss of about $80 \mathrm{mV}$ is due to the ohmic drop and the remaining loss of $120 \mathrm{mV}$ must be ascribed to electrokinetic and mass transport constraints (flooding) in the oxide supported catalyst.

Ohmic drop-corrected Tafel plots for the oxygen reduction reaction (ORR) with the current normalised with respect to the Pt loading are shown for the three catalysts in Fig. 8 at $80{ }^{\circ} \mathrm{C}$. The Tafel slope was around $70 \mathrm{mV} / \mathrm{dec}$ for the PtCo catalysts in agreement with a Temkin adsorption condition for the coverage of oxygenated species [44]. The potential difference for the two PtCo catalysts in the Tafel plots was around $100 \mathrm{mV}$ in the eletrokinetic region. This gap can be attributed almost entirely to the electrokinetic losses. The mass activity at $0.9 \mathrm{~V}$ RHE has increased from 32 to $316 \mathrm{~mA} / \mathrm{mg}_{\mathrm{Pt}}$ (about one order of magnitude) passing from $\mathrm{PtCo} / \mathrm{oxide}$ to $\mathrm{PtCo} / \mathrm{C}$ catalyst. In the literature, a mass activity at $0.9 \mathrm{~V} \mathrm{RHE}$ of $18 \mathrm{~mA} / \mathrm{mg}$ and a Tafel slope of 113 $\mathrm{mV} / \mathrm{dec}$ at ambient temperature have been recently reported for a composite $\mathrm{Pt} / \mathrm{TiO}_{2}$-carbon catalyst [27]. Whereas, there are not many reports concerning with the mass activity determination under practical fuel cell operating conditions for oxide-supported catalysts. At $0.85 \mathrm{~V}$ RHE, the mass activity of the $\mathrm{PtCo} /$ oxide catalyst has reached $186 \mathrm{~mA} / \mathrm{mg}_{\mathrm{Pt}}$ that was just slightly lower than that recorded for the best Pt/Ebonex catalysts (219 mA/mg@0.85 V RHE) [19]. However, it is observed that the performance in a fuel cell at conventional operating conditions is still not appropriate for the present oxide supported PtCo alloy. By examining the in-situ CV profiles (Fig. 9), it appears evident that the electrochemically active surface area is significantly lower for the oxide-supported catalysts (Table 1). On the other hand, it can be observed a shift of the Pt-oxide

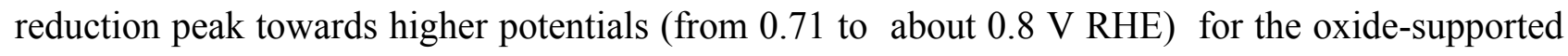
catalysts compared to the carbon supported one (Fig. 9). This may be indicative of a better intrinsic (specific) activity for the oxygen reduction [45-46]. Such effect is not necessarily caused by the different supports but it may be due to the Pt particle agglomeration and the lower active surface 
area in the oxide-supported catalysts [47-49]. However, such possible increase in specific activity does not compensate the negative effects of the decrease of surface area. Since the dimension of the primary crystallites was similar in these catalysts as observed from XRD, we should assume that the agglomeration in the oxide supported catalysts is mainly responsible for such poor electrochemical active surface area. On the other hand, such agglomeration of particles on the support to form an almost continuous metal layer appears appropriate in order to improve electronic percolation through the surface for the modest conductivity of the oxide. However, this approach, in parallel, decreases the catalyst utilization and a proper compromise appears thus necessary. Beside this aspect, the catalyst-support interaction may affect the value of surface area for the oxide supported catalysts. The interaction between oxide support and dispersed metal catalyst was studied in the literature by X-ray absorption near edge structure spectroscopy (XANES) [22]. It was shown that this interaction can cause a decrease of $\mathrm{OH}$ coverage on $\mathrm{Pt}$ and an enhancement of the specific activity. The oxide support may also cause spillover effects for other adsorbed species such as hydrogen. Accordingly, a decrease of the current density for the $\mathrm{Pt}-\mathrm{H}$ and $\mathrm{Pt}-\mathrm{OH}$ waves is expected in the case of strong-metal support interaction since the Pt atoms involved in this strong bond with the support are not available for the electrochemical process. Thus, the metal-support interaction may significantly affect the ECSA in the oxide-supported catalyst $[19,50,51]$.

By increasing the temperature at $100{ }^{\circ} \mathrm{C}$ under pressurised conditions and maintaining full humidification, the oxide supported catalysts showed still relevant electrokinetic losses with respect to the $\mathrm{PtCo} / \mathrm{C}$ catalyst (Fig. 10a). A larger slope at high current densities was also present. This could be due to the ohmic drop induced by the oxide support (Fig. 10a). However, the mass transport limitations previously envisaged for the oxide supported catalysts were not observed at $100{ }^{\circ} \mathrm{C}$, possibly due to the fact that the higher temperature promotes mass transport or reduces the flooding of the catalytic layer. The voltage gap at $1 \mathrm{~A} \mathrm{~cm}^{-2}$ was decreased for the two PtCo catalysts from $200 \mathrm{mV}$ to $160 \mathrm{mV}$ passing from $80^{\circ}$ to $100{ }^{\circ} \mathrm{C}$ (Fig. 10a). Being the series resistance similar to that observed at $80{ }^{\circ} \mathrm{C}$, this decrease of voltage gap can be assigned to a decrease of 
electrokinetic and mass transfer constraints. Ohmic drop-corrected Tafel plots are reported in Fig. 10b. In this specific case, the voltage gap at $100{ }^{\circ} \mathrm{C}$ between the two PtCo catalysts was $50-60 \mathrm{mV}$ whereas it was $100 \mathrm{mV}$ at $80{ }^{\circ} \mathrm{C}$. Thus, the decrease of voltage gap was mainly due to improved reaction electrokinetics for the oxide supported catalyst and in a minor part to enhanced mass transfer characteristics. By decreasing at $100{ }^{\circ} \mathrm{C}$ the R.H. to $33 \%$ at $100{ }^{\circ} \mathrm{C}$, the overall voltage gap at $1 \mathrm{~A} \mathrm{~cm}^{-2}$ between the two PtCo catalysts was further decreased to $136 \mathrm{mV}$ (Fig. 11a) with respect to $160 \mathrm{mV}$ under full humidification at the same temperature; however, the difference in potential in the Tafel plots has remained $60 \mathrm{mV}$ (Fig. 11b) indicating that a change of R.H. under this conditions does not affect electrokinetics but probably reduces the flooding. The mass activity of the PtCo/oxide catalyst for ORR at $100{ }^{\circ} \mathrm{C}, 33 \%$ R.H. and $0.85 \mathrm{~V}$ RHE was larger than that recorded at $80^{\circ} \mathrm{C}, 100 \%$ R.H. at the same potential (251 vs. $186 \mathrm{~mA} / \mathrm{mg}$ ). It is worth considering that under pressurised conditions at $100{ }^{\circ} \mathrm{C}$, there were no significant effects of ionomer dry-out in the catalytic layer; however, at 33\% R.H., a slight increase of ohmic resistance associated to proton transport in the membrane was observed. The different ohmic behaviour for the MEA based on oxide or carbon black supports, observed at $80^{\circ} \mathrm{C}$ under full humidification, appeared less exacerbated at high temperature and lower R.H.

The performance of these catalysts was thus investigated under conditions that are generally relevant for automotive applications i.e. intermediate temperature $\left(110^{\circ} \mathrm{C}\right)$ and low relative humidity (R.H. 33\%). Under such conditions, the proton transport in the membrane and ionomer dry-out effects in the catalytic layer may play an important role and affect the catalytic activity at the interface. An increase both in terms of voltage drop in the activation region and slope at intermediate current density were observed in the polarization curves (Fig. 12a). The performance of the Pt catalyst was much lower than that of the PtCo alloys (Fig. 12a). The PtCo/oxide catalyst performance was approaching that of the carbon supported catalyst with a voltage gap of just 60 $\mathrm{mV}$ (Fig. 12a) observed in a wide current density range of practical interest (400-900 $\mathrm{mA} \mathrm{cm}^{-2}$ ). Under these conditions $\left(110^{\circ} \mathrm{C}\right.$ and $33 \%$ R.H. $)$, the main drawbacks of the PtCo/oxide catalyst vs. 
the carbon supported one, i.e. lower electrochemically active surface area and electronic percolation, has appeared less relevant than at $80{ }^{\circ} \mathrm{C}$. It seems that the elevated temperature can promote reaction kinetics for the oxide supported PtCo catalyst through mitigation of the effects related to a less effective water assisted proton transport mechanism. In other words, we think that the hydrophilicity of the oxide support and its water retention properties, already demonstrated in fuel cell [52], are of relevant impact for high temperature operation since these characteristics can mitigate ionomer dry-out effects. The TG analysis of the Ta-doped Ti-oxide support (Fig.12b) showed a continuous weight loss until $300{ }^{\circ} \mathrm{C}$. The DSC profile showed an endothermic peak at about $50{ }^{\circ} \mathrm{C}$ and an exothermic peak at about $300{ }^{\circ} \mathrm{C}$ corresponding to the loss of physically and chemically adsorbed water. This evidence was compatible with the water retention mechanism at intermediate temperatures during fuel cell operation. A second weight loss mechanism, clearly distinguishable from the first one but significantly smaller, was observed above $325{ }^{\circ} \mathrm{C}$. This was ascribed to the removal of surface hydroxyl groups (there were no organic residues in this sample being prepared from an inorganic route). The latter process showed an endothermic peak at $400{ }^{\circ} \mathrm{C}$ partially overlapping with the one occurring at $300{ }^{\circ} \mathrm{C}$. Since the material was prepared at $400{ }^{\circ} \mathrm{C}$, its thermal properties were not investigated at very high temperatures. It is pointed out that the sample was characterised by the crystallographic Anatase structure in the low temperature range. At $650{ }^{\circ} \mathrm{C}$, the onset of the phase transition to Rutile was observed. The water retention characteristics of the oxide support can allow to recover part of the performance gap with respect to carbonsupported electrocatalysts or promote the ORR under automotive relevant operating conditions.

As discussed above, one relevant problem affecting carbon supported Pt catalysts is their poor stability at high electrochemical potentials. High potentials are experienced by the catalyst during cycled operation, during OCV transients and under fuel starvation conditions $[2,3,41,53,54]$. These aspects are especially relevant for the automotive applications since they affect the life-time of the fuel cell stack [3]. The use of an oxide instead of a carbon black or a graphitic carbon support is promoted by the perspective of achieving an increased stability under critical conditions. The most 
used accelerated stress test (AST) protocols in the literature consist in electrochemical step cycles between 0.6 and $0.9 \mathrm{~V}$ under fuel cell operation or cycling voltammograms in half cell in the range 0.05-1.25 V [33,38,55,56]. However, these stress tests do not account for the fuel starvation condition (potential increase up to $1.4 \mathrm{~V}$ RHE) and are considered much less aggressive with respect to a potential holding experiment at high electrochemical potentials $[3,55]$. In fact, the electrochemical corrosion is essentially driven by the electrochemical potential and the acidic environment whereas relative humidity and temperature play a minor role [4-6]. Accordingly, we have analysed the variation of electrochemical active surface area for the three catalysts in a sulphuric acid electrolyte half cell after potential holding at $1.4 \mathrm{~V}$ RHE using a Ti grid as both backing layer and current collector.

The variation of normalised ECSA, i.e. the ECSA recorded during the experiment, referred to its value at the beginning of the test, is reported as a function of time in Fig. 13. Under such extremely corrosive conditions, the carbon supported PtCo catalyst shows a dramatic decrease of electrochemical active surface area. After $2 \mathrm{~h}$ at $1.4 \mathrm{~V}$ RHE, about $50 \%$ of ECSA is lost in the $\mathrm{PtCo} / \mathrm{C}$ catalyst (Fig. 13). This result is the direct consequence of carbon oxidation to $\mathrm{CO}_{2}$. Since Pt nanoparticles are supported on carbon, when the support is corroded, these are lost into the ionomer or in the membrane forming electrically isolated Pt particles. Completely different is the situation for $\mathrm{Pt}$ and PtCo catalysts dispersed on the oxide support. The oxide is inert under these conditions, moreover, at 1.4 V RHE, a stable and protective Pt-oxide layer is formed. Curiously, the ECSA increases with respect to its initial value at the beginning of the stress test in both oxidebased catalysts (Fig. 13). This increase is the largest for the Pt/oxide catalyst where an almost 100\% increase in ECSA is recorded before reaching a steady-state condition (Fig. 13). At the moment, it is difficult to interpret this phenomenon. It may be due to a surface corrugation induced by the formation of the oxide layer; however, such an increase of ECSA should be in principle more pronounced in the case of PtCo since Co atoms on the surface can be leached under corrosive conditions. Whereas, the PtCo/oxide catalyst shows a less pronounced effect. As speculative 
hypothesis, we can assume that the metal-support interaction is diminished under these oxidizing conditions and some Pt sites which were involved in the metal-support interaction are available for the electrochemical process after this electrochemical activation. It is useful to mention that a large $\mathrm{OH}_{\mathrm{ad}}$ coverage on the electrode surface has been observed in the literature for Pt dispersed on a ceramic support compared to $\mathrm{Pt} / \mathrm{C}$ [57]. This effect could influence the ECSA causing remarkable enhancement during operation [57].

TEM observations of the catalytic layers scraped from the electrodes (Fig. 14), apparently, do not show relevant morphology change in the Pt/oxide catalyst after the stress test at $1.4 \mathrm{~V}$ RHE. Indeed, the presence of the ionomer/oxide catalyst mixture does not allow to distinguish clearly the primary particles in this catalyst. However, at the edges of the support agglomerates, we can see primary particles with a slightly enhanced interparticle distance with respect to the raw material (Fig.14). In the case of $\mathrm{PtCo} / \mathrm{C}$ subjected to the degradation test at $1.4 \mathrm{~V}$ RHE, it is clearly observed a strong degradation of the carbon black support, a growth of metal particles with respect to the raw catalyst, the presence of uncatalysed regions as compared to the raw material. These relevant changes of the morphology clearly indicate that dissolution and re-precipitation phenomena which involve Pt particles have occurred during the test and such evidences provide an explanation for the large loss of surface area.

The accelerated stress test at $1.4 \mathrm{~V}$ RHE reveals that the oxide supported PtCo catalyst is substantially stable under extremely corrosive conditions. Thus, during the life-time of the fuel cell system, this oxide supported catalyst may reach and surpass the performance of a carbon black based catalyst that instead experiences strong degradation effects due to the electrochemical corrosion of carbon. Thus, it is important a further progress to produce an amelioration of the performance of the oxide-supported alloy catalyst in combination with the perspectives of enhanced stability. In parallel, the addition of a stable conductive carbonaceous material into ceramic supports may be also promising. This has shown to greatly improve the ECSA while assuring increased stability [58]. 


\section{Conclusions}

Ta-doped Ti-oxide supported Pt and PtCo alloy catalysts have been investigated for the oxygen reduction process in PEMFCs. The relevant properties of these materials for operation as cathode in PEM fuel cell were compared to those of a carbon supported $\mathrm{Pt}_{3} \mathrm{Co}_{1}$ alloy. This is considered as one of the most performing and reliable materials among the cathode catalysts presently used in fuel cells.

All catalysts were characterised by a similar crystallite size; however, the carbon supported one was performing better in fuel cell under low temperature operation due to a larger electrochemical active surface area and lower ohmic drop constraints. The oxide-supported PtCo alloy showed superior electrocatalytic activity than the Pt/oxide catalyst. The performance gap between oxidesupported and carbon-supported PtCo alloys was progressively decreased by increasing operating temperature and decreasing relative humidity. This behaviour appears to be related to the hydrophilicity of the oxide support and its water retention properties at intermediate temperature. Such characteristics may significantly reduce the drawback of ionomer dry-out under automotive operating conditions (high temperature and low relative humidity). It was observed that at $110{ }^{\circ} \mathrm{C}$ and $33 \%$ R.H., the cell potential for the carbon and oxide-supported cathode electrocatalysts differed by only $60 \mathrm{mV}$. As a relevant aspect, oxide supported catalysts showed a much better resistance to electrochemical corrosion than the carbon supported one in an accelerated stress test at 1.4 V RHE. Thus, a larger durability is expected for the oxide supported catalysts.

Accordingly, it is derived that supporting a Pt alloy on doped Ti-oxides is a promising route for enhancing PEM fuel cell stability. This approach is also useful to enhance the oxygen reduction reaction at intermediate temperatures and low R.H. due to the suitable water retention characteristics of the oxide support. Both aspects appear of relevant interest for automotive applications. 


\section{Acknowledgements}

The authors acknowledge the financial support of the EU through the QuasiDry Project 256821. The research leading to these results has received funding from the European Community's Seventh Framework Programme (FP7/2010-2013) under the call ENERGY-2010-10.2-1: Future Emerging Technologies for Energy Applications (FET).

Special thanks are due to Dr. S. Siracusano for oxide support BET surface area measurement, Ms. E. Modica for the assistance in electrochemical corrosion tests and Mr. G. Monforte for XPS measurements. 


\section{References}

[1] A.S. Aricò, P.L. Antonucci, V. Antonucci, "Metal-support interaction in low temperature fuel cell electrocatalysts" in: A. Wieckowski, E.R. Savinova, C.G. Vayenas (Eds.), Catalysis and Electrocatalysis at Nanoparticle Surfaces, Marcel Dekker, Inc., New York, 2003, ISBN: 0-82470879-2.

[2] D. Sebastián, I. Suelves, E. Pastor, R. Moliner, M. J. Lázaro, Applied Catalysis B: Environmental 132- 33 (2013) 13-21.

[3] H.A. Gasteiger, S.S. Kocha, B. Sompalli, F.T. Wagner, Appl. Catal. B: Environ. 56 (2005) 9-35.

[4] R.L. Borup, J.R. Davey, F.H. Garzon, D.L. Wood, M.A. Inbody, J. Power Sources 163 (2006) 76-81.

[5] H.R. Colon-Mercado, B.N. Popov, J. Power Sources 155 (2006) 253-263.

[6] A.S. Aricò, A. Stassi,E. Modica, R. Ornelas, I. Gatto, E. Passalacqua, V. Antonucci, J. Power Sources 178 (2008) 525-536.

[7] T. Ioroi, H. Senoh, S. Yamazaki, Z. Siroma, N. Fujiwara, K. Yasuda, J. Electrochem. Soc. 155, (2008) B321-B326.

[8] F. Takasaki, S. Matsuie, Y. Takabatake, Z. Noda, A. Hayashi, Y. Stiratori, K. Ito, K. Sasaki, J. Electrochem. Soc. 158 (2011) B1270-B1275.

[9] A. Masao, S. Noda, F. Takasaki, K. Ito, K. Sasaki, Electrochem. Solid-State Lett. 12 (2009) B119-B122.

[10] K. Kakinuma, M. Uchida, T. Kamino, H. Uchida, M. Watanabe, Electrochim. Acta 56 (2011) 2881-2887.

[11] K. Kakinuma, Y. Wakasugi, M. Uchida, T. Kamino, H. Uchida, S. Deki, M. Watanabe, Electrochim. Acta 77 (2012) 279-284.

[12] K. Kakinuma, Y. Wakasugi, M. Uchida, T. Kamino, H. Uchida, M. Watanabe, Electrochemistry 79 (2011) 399-403. 
[13] D.H. Lim, W.J. Lee, N.L. Macy, W.H. Smyrl, Electrochem. Solid-State Lett. 12 (2009) B123B125.

[14] S. Yin, S. Mu, M. Pan, Z. Fu, J. Power Sources 196 (2011) 7931-7936.

[15] B. Avasarala, P. Haldar, Electrochim. Acta 55 (2010) 9024-9034.

[16] B. Wickman, M. Wesselmark, C. Lagergren, G. Lindbergh, Electrochim.Acta 56 (2011) 94969503.

[17] Y. Shao, J. Liu, Y. Wang, Y. Lin, J. Mater. Chem., 19 (2009) 46-59.

[18] T. Ioroi, Z. Siroma, N. Fujiwara, S. Yamazaki and K. Yasuda, Electrochem. Commun. 7 (2005) 183-188.

[19] Lj. M. Vračar, N.V. Krstajić, V.R. Radmilović, M.M. Jakšic, J. Electroanal. Chem. 587 (2006) 99-107.

[20] J. A. Tian, G. Q. Sun, L. H. Jiang, S. Y. Yan, Q. Mao, Q. Xin, Electrochem. Commun., 9 (2007) 563-568.

[21] S. Siracusano, V. Baglio, C. D'Urso, V. Antonucci, A.S. Aricò, Electrochim. Acta 54 (2009) 6292-6299.

[22] K.W. Park, K.S. Seol, Electrochem. Commun. 9 (2007) 2256-2260.

[23] N. Giordano, P.L. Antonucci, E. Passalacqua, L. Pino, A.S. Aricò, K. Kinoshita, Electrochim. Acta 36 (1991) 1931-1935.

[24] L. Xiong, A. Manthiram, Electrochim. Acta, 49 (2004) 4163-4170.

[25] H. Q. Song, X. P. Qiu, F. S. Li, W. T. Zhu, L. Q. Chen, Electrochem. Commun. 9 (2007) 14161421.

[26] S. Shanmugam, A. Gedanken, Small 3 (2007) 1189-1193.

[27] A. Bauer, C. Song, A. Ignaszak, R. Hui, J. Zhang, L. Chevallier, D. Jones, J. Roziere, Electrochim. Acta 55 (2010) 8365-8370.

[28] S. Beak, D. Jung, K.S. Nahm, P. Kim, Catal. Lett. 134 (2010) 228-294.

[29] X. Liu, J. Chen, G. Liu, L. Zhang, H. Zhang, B. Yi , J. Power Sources, 195 (2010) 4098- 4103. 
[30] G. Y. Chen, S. R. Bare,T. E. Mallouk, J. Electrochem. Soc., 149 (2002) A1092- A1099.

[31] H. Ekstrom, B. Wickman, M. Gustavsson, P. Hanarp, L. Eurenius, E. Olsson and G. Lindbergh, Electrochim. Acta, 52 (2007) 4239-4245.

[32] S-Y Huang, P. Ganesan, B. N. Popov, Appl. Catal. B 102 (2011) 71-77.

[33] A. Bauer, K. Lee, C. Song, Y. Xie, J. Zhang, R. Hui, J. Power Sources 195 (2010) 3105-3110.

[34] T. B. Do, M. Cai, M. S. Ruthkosky, T. E. Moylan, Electrochim. Acta 55 (2010) 8013-8017.

[35] F.C. Walsh, R.G.A. Wills, Electrochim. Acta 55 (2010) 6342-6351.

[36] M. Hepel, I. Dela, T. Hepel, J. Luo, C. J. Zhong, Electrochim. Acta 52 (2007) 5529-5547.

[37] V.R. Stamenkovic, B.S. Mun, M. Arenz, K.J.J. Mayrhofer, C.A. Lucas, G. Wang, P.N. Ross, N.M. Markovic, Nat. Mater. 6 (2007) 241- 247.

[38] A.S. Aricò, A. Stassi, I. Gatto, G. Monforte, E. Passalacqua, V. Antonucci, J. Phys. Chem. C $114(2010)$ 15823-15836.

[39] A.S. Aricò, A. Di Blasi, G. Brunaccini, F. Sergi, G. Dispenza, L. Andaloro, M. Ferraro, V. Antonucci, P. Asher, S. Buche, D. Fongalland, G.A. Hards, J.D.B. Sharman, A. Bayer, G. Heinz， N. Zandonà, R. Zuber, M. Gebert, M. Corasaniti, A. Ghielmi, D.J. Jones, Fuel Cells 10 (2010) 1013-1023.

[40] A. Stassi, I. Gatto, G. Monforte, V. Baglio, E. Passalacqua, V. Antonucci, A.S. Aricò, J. Power Sources 208 (2012) 35-45.

[41] S.D. Knights, K.M. Colbow, J. St-Pierre, D.P. Wilkinson, J. Power Sources 127 (2004) 127134.

[42] T.W. Patterson, R.M. Darling, Electrochem. Solid State Lett. 9 (2006) A183- A185.

[43] A. Garsuch, D. A. Stevens, R. J. Sanderson, S. Wang, R. T. Atanasoski, S. Hendricks, M. K. Debe, J. R. Dahn, J. Electrochem. Soc. 157 (2010) B187-B194.

[44] A.S. Aricò, V. Antonucci, V. Alderucci, E. Modica, N. Giordano, J. Applied Electrochem., 23 (1993) 1107-1116. 
[45] M. Wesselmark, B. Wickman, C. Lagergren, G. Lindbergh, Electrochim. Acta, 55 (2010) $7590--7596$.

[46] D. Kim, Essam F. A. Zeid, Y.-T. Kim, Electrochim. Acta, 55 (2010) 3628-3633.

[47] F. Maillard, S. Schreier, M. Hanzlik, E. R. Savinova, S. Weinkauf, U. Stimming, Phys. Chem. Chem. Phys. 7 (2005) 385-393.

[48] Y. Takasu, N. Ohashi, X.-G. Zhang, Y. Murakami, H. Minagawa, S. Sato, K. Yahikozawa, Electrochim. Acta 41 (1996) 2595- 2600.

[49] O.V Cherstiouk, P.A Simonov, E.R Savinova, Electrochim. Acta 48 (2003) 3851-3860.

[50] Torre T., Aricò, A.S., Alderucci, V., Antonucci, V., Giordano, N. Applied Catalysis A, General, 114 (1994) 257-272.

[51] N.R. Elezović, B.M. Babić, Lj. Gajić-Krstajić, V. Radmilović, N.V. Krstajić, L.J. Vračar, J. Power Sources 195 (2010) 3961-4422.

[52] V. Baglio, A.S. Aricò, A. Di Blasi, V. Antonucci, P.L. Antonucci, S. Licoccia, E. Traversa, F. Serraino Fiory, Electrochimica Acta 50 (2005) 1241-1246.

[53] S. Song, Y. Liang, Z. Li, Y. Wang, R. Fu, D. Wu, P. Tsiakaras, Applied Catalysis B: Environ. 98 (2010) 132-137.

[54] S. Zhang, Y. Y. Shao, G. P. Yin, Y. H. Lin, Applied Catalysis B: Environ. 102 (2011) 372-377.

[55] R. Borup, J. Meyers, B. Pivovar, Y.S. Kim, R. Mukundan, N. Garland, D. Myers, M. Wilson, F. Garzon, D. Wood, P. Zelenay, K. More, K. Stroh, T. Zawodzinski, J. Boncella, J.E. McGrath, M. Inaba, K. Miyatake, M. Hori, K. Ota, Z. Ogumi, S. Miyata, A. Nishikata, Z. Siroma, Y. Uchimoto, K. Yasuda, K. I. Kimijima and N. Iwashita, Chem. Rev., 107 (2007) 3904- 3951.

[56] T. Kottakkat, A. K. Sahu, S. D. Bhat, P. Sethuraman, S. Parthasarathi, Appl. Catal. B: Environ. $110(2011) 178-185$.

[57] H.F. Lv, T. Peng, P. Wu, M. Pan, S.C. Mu, J. Mat. Chem., 22 (2012) 9155- 9160.

[58] H.F. Lv, S.C. Mu, N.C. Cheng, M. Pan. Appl. Catal. B: Environ., 100 (2010) 190-196. 


\section{Captions to Figures}

Fig. 1 XRD patterns and TEM micrograph (inset) of the $\mathrm{Ti}_{0.75} \mathrm{Ta}_{0.25} \mathrm{O}_{2}$ support used for preparing fuel cell catalysts.

Fig. 2 XRD patterns of oxide supported Pt and PtCo alloy and carbon supported PtCo alloy.

Fig. 3 TEM micrographs of oxide supported Pt (a) and PtCo alloy (b) and carbon supported PtCo alloy (c).

Fig. 4 X-ray photoelectron survey spectra of oxide supported and carbon supported PtCo catalysts.

Fig. 5 High resolution X-ray photoelectron spectra of the Pt4f region in oxide supported and carbon supported PtCo catalysts.

Fig. 6 Polarization curves for the PEM fuel cells based on oxide supported Pt (a) and PtCo alloy (b) and carbon supported PtCo alloy (c) at $80{ }^{\circ} \mathrm{C}$ and $100 \%$ R.H.

Fig. 7 Ac-impedance spectra at $0.7 \mathrm{~V}$ for the PEM fuel cells based on oxide supported Pt (a) and PtCo alloy (b) and carbon supported PtCo alloy (c) at $80^{\circ} \mathrm{C}$ and $100 \%$ R.H.

Fig. 8 IR-free Tafel plots for oxide supported Pt (a) and PtCo alloy (b) and carbon supported PtCo alloy (c) at $80{ }^{\circ} \mathrm{C}$ and $100 \%$ R.H.

Fig. 9 In-situ cyclic voltammetry for oxide supported Pt (a) and PtCo alloy (b) and carbon supported PtCo alloy (c).

Fig. 10 Polarization curves (A) and corresponding Tafel plots (B) for oxide supported Pt (a) and PtCo alloy (b), and carbon supported PtCo alloy (c) at $100{ }^{\circ} \mathrm{C}, 100 \%$ R.H., 3 bar abs.

Fig. 11 Polarization curves (A) and corresponding Tafel plots (B) for oxide supported Pt (a) and PtCo alloy (b), and carbon supported PtCo alloy (c) at $100{ }^{\circ} \mathrm{C}$ and $33 \%$ R.H., 3 bar abs.

Fig. 12 (a) Polarization curves for oxide supported Pt and PtCo alloy, and carbon supported PtCo alloy at $110{ }^{\circ} \mathrm{C}$ and $33 \%$ R.H., 3 bar abs. (b) TG-DSC curves for the Ta-doped Ti-oxide.

Fig. 13 Variation of the normalised electrochemically active surface area for oxide supported Pt and PtCo alloy, and carbon supported PtCo alloy during an accelerated stress test in half cell consisting of potential holding at $1.4 \mathrm{~V}$ (RHE). 
Fig. 14 TEM micrographs of oxide supported Pt (a) and carbon supported PtCo (b) electro-catalysts after the accelerated stress test at $1.4 \mathrm{~V}$ vs. RHE. 


\section{Table 1}

Catalyst properties.

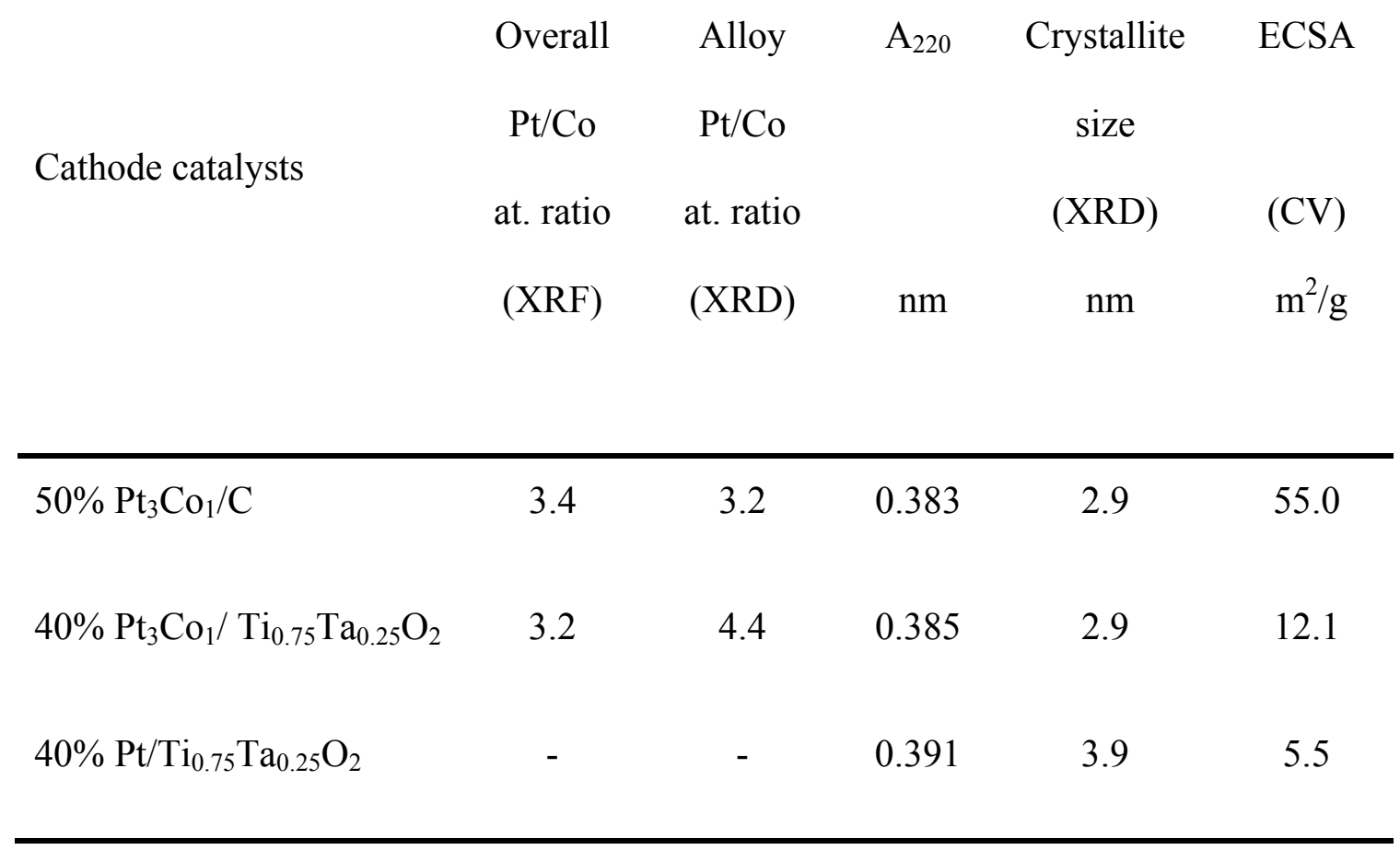


Figure(1)

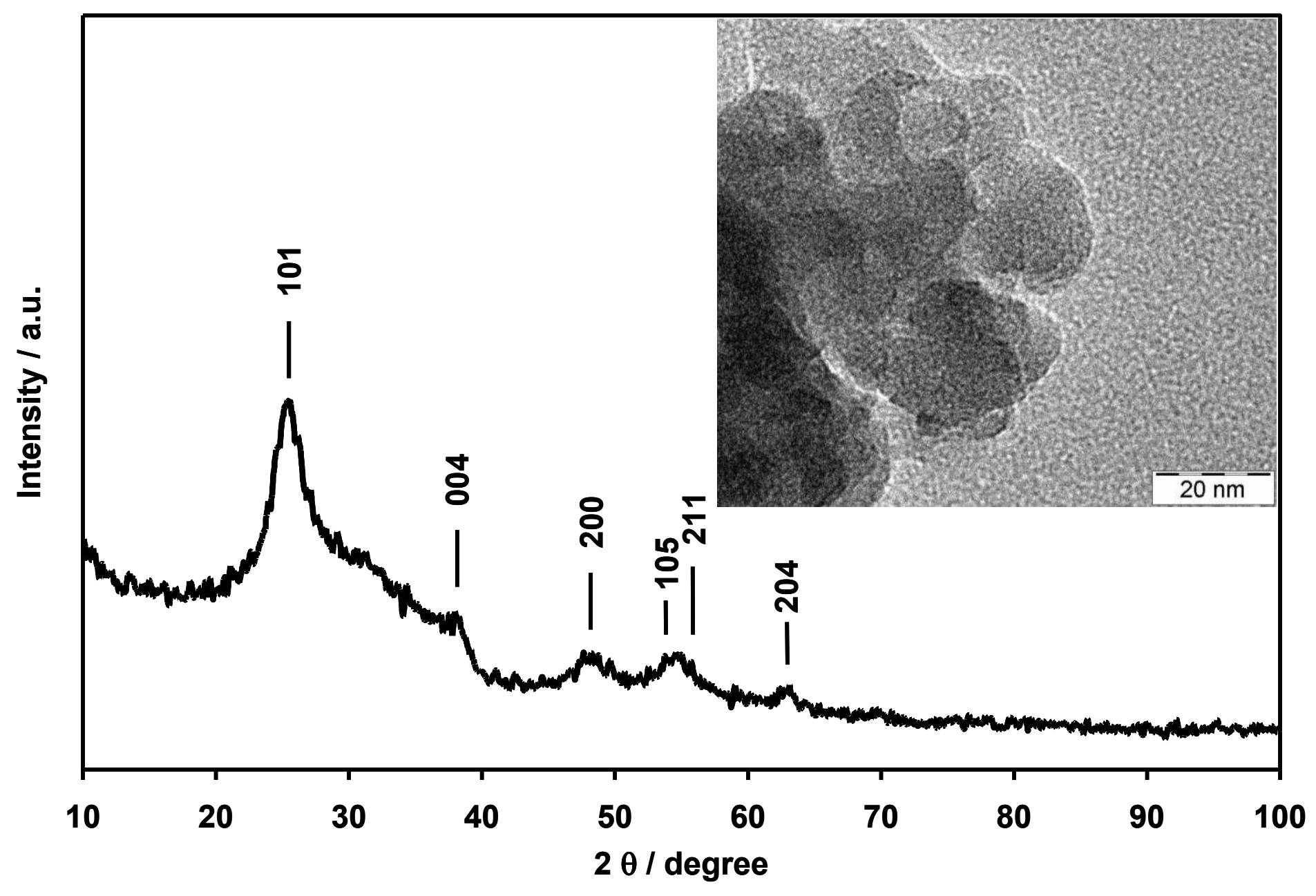

Fig.1 


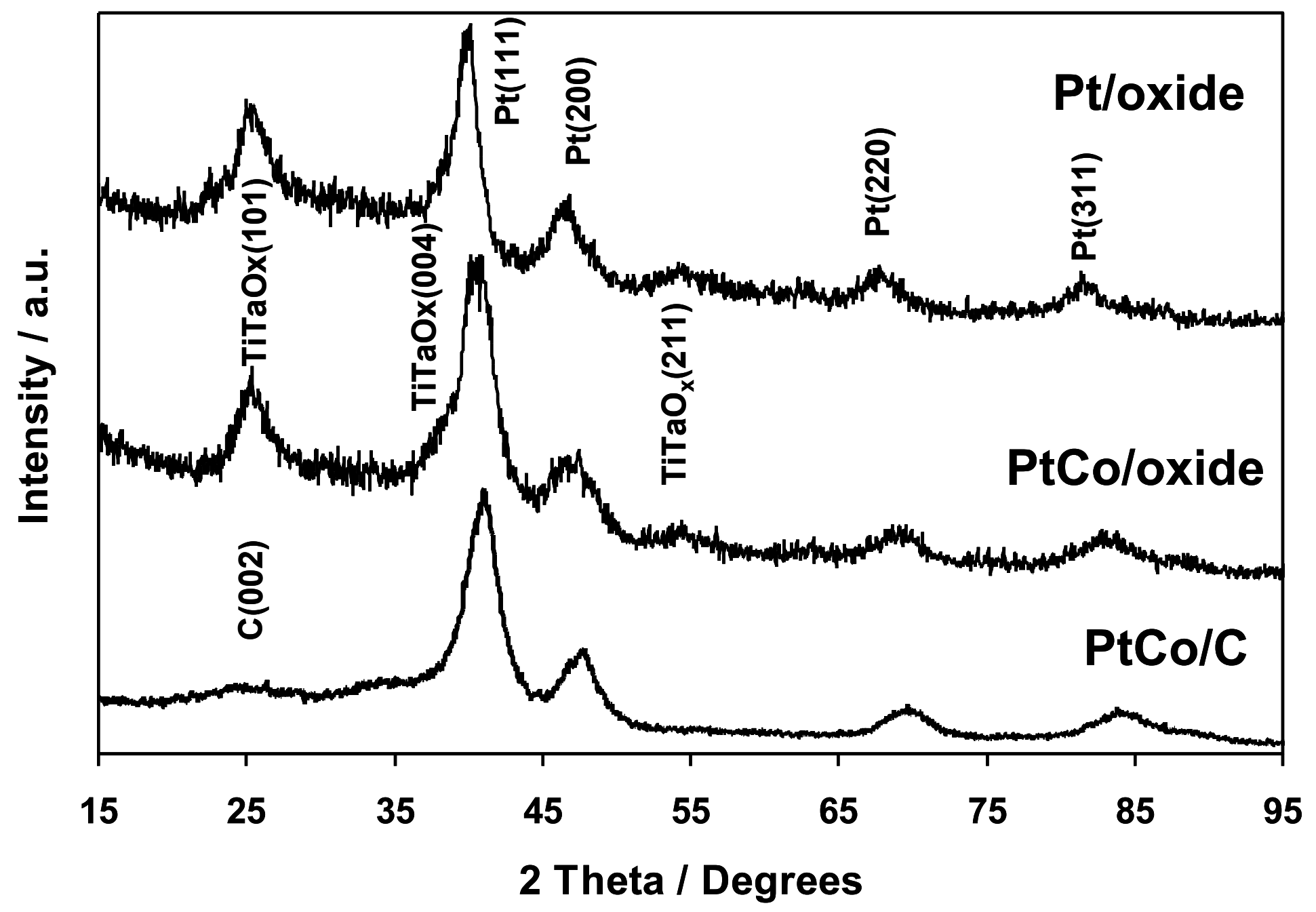

Fig. 2 
Figure(3)
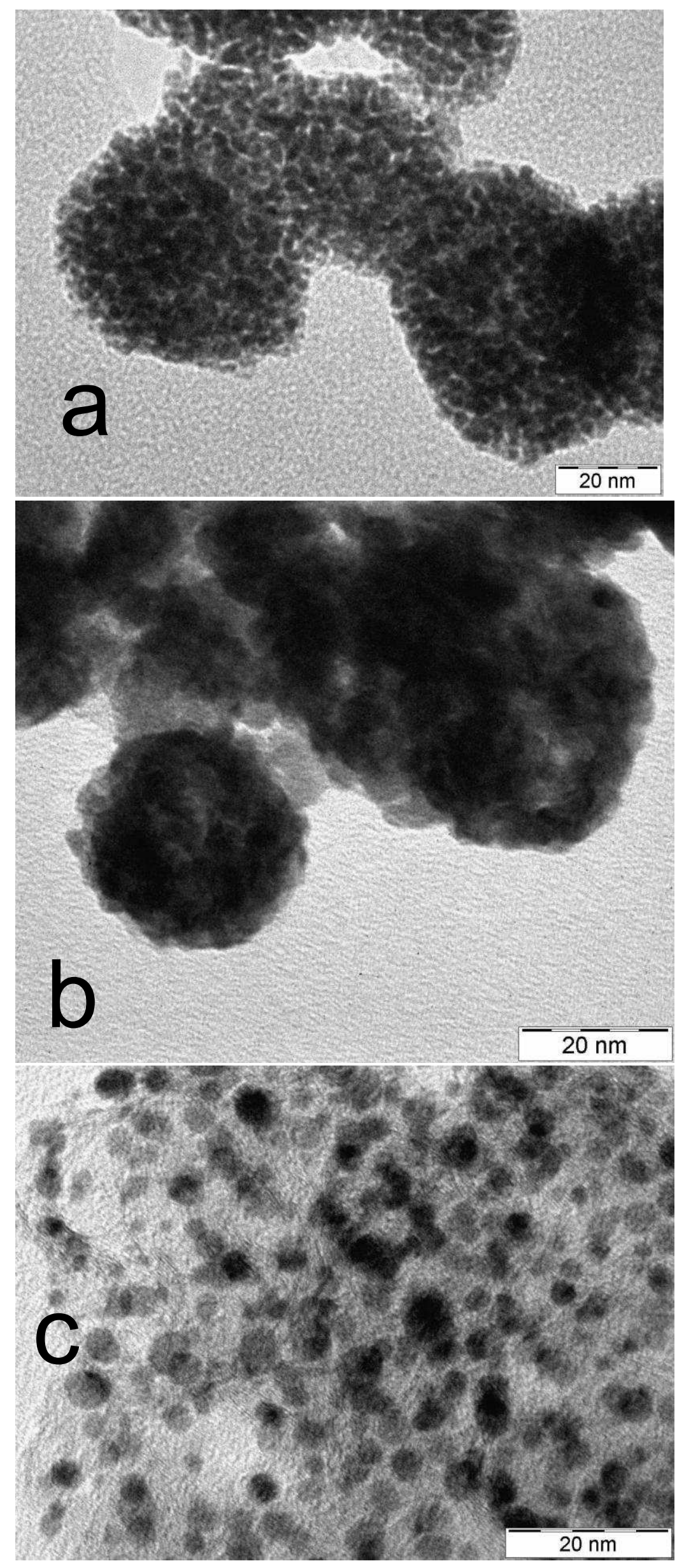

Fig. 3

3


Counts / a.u.

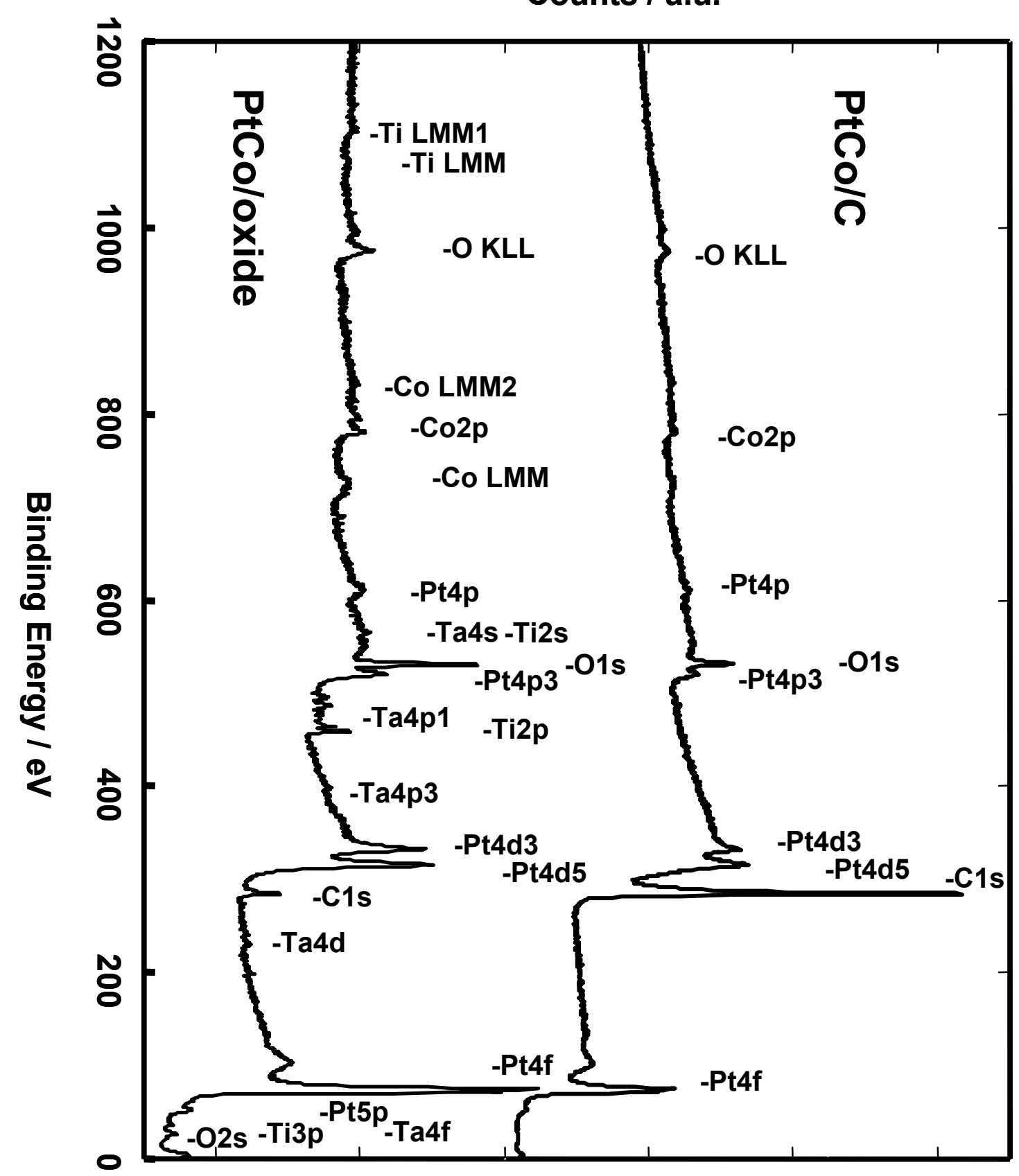



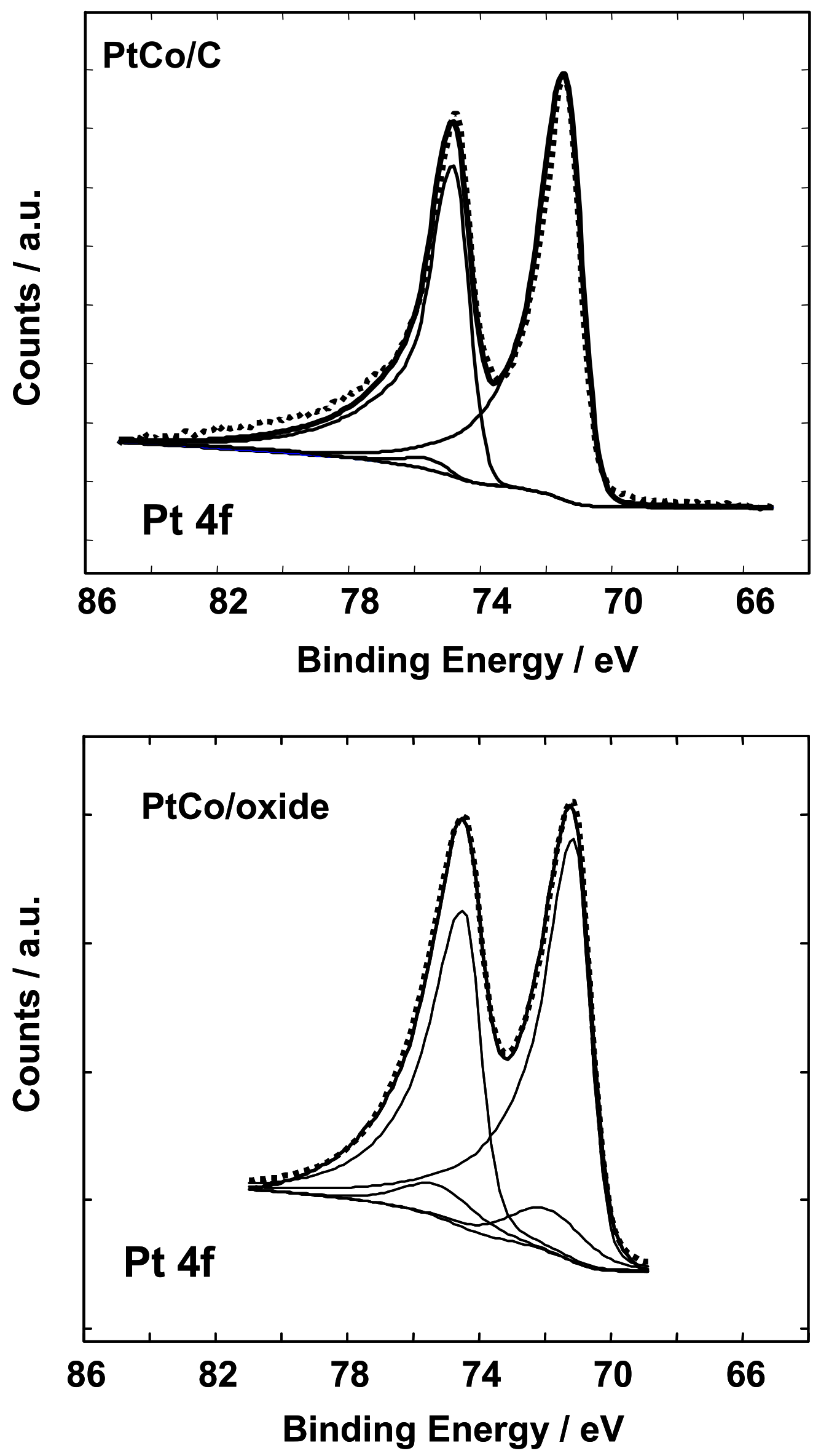

Fig. 5 


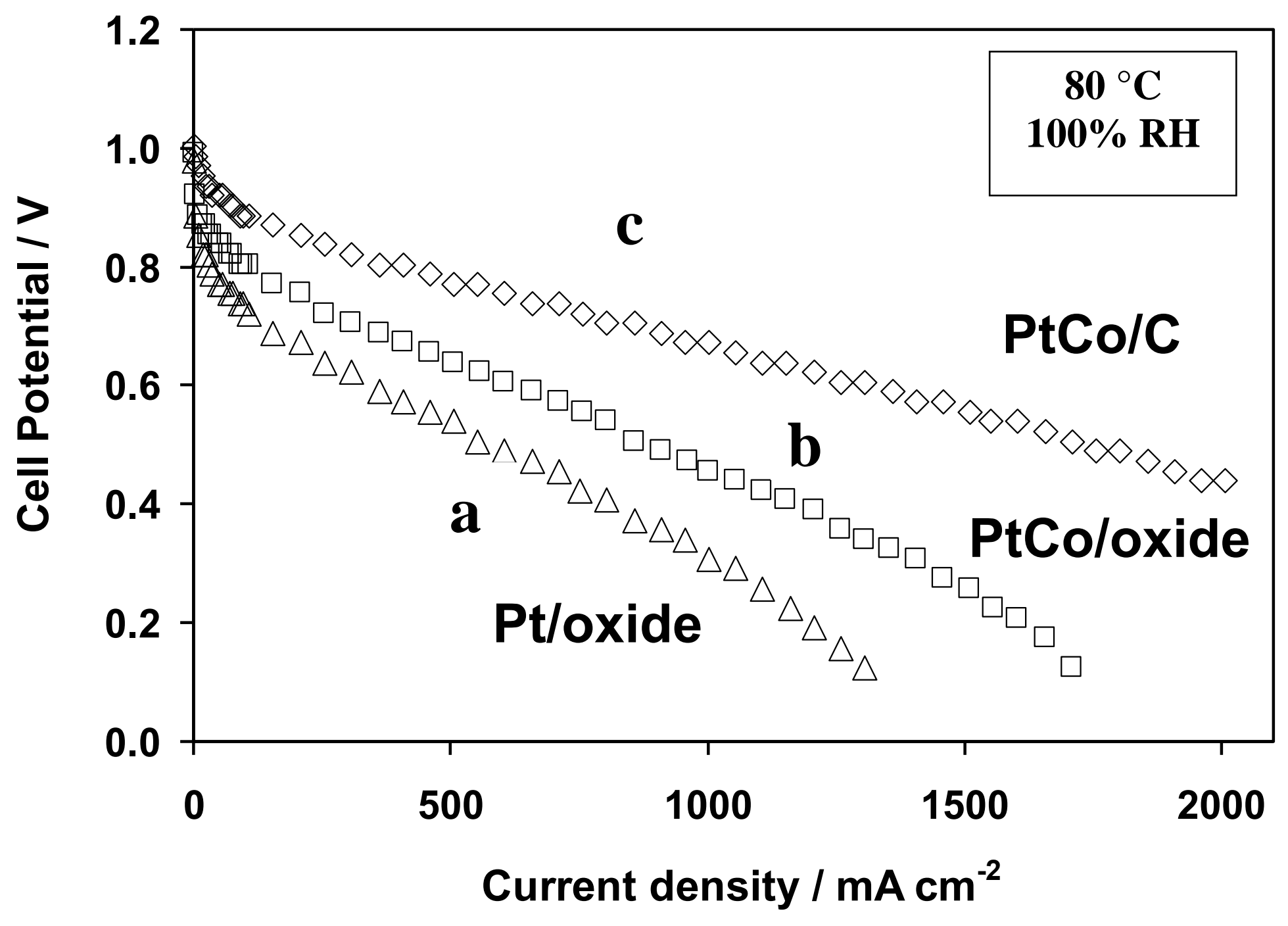

Fig. 6 


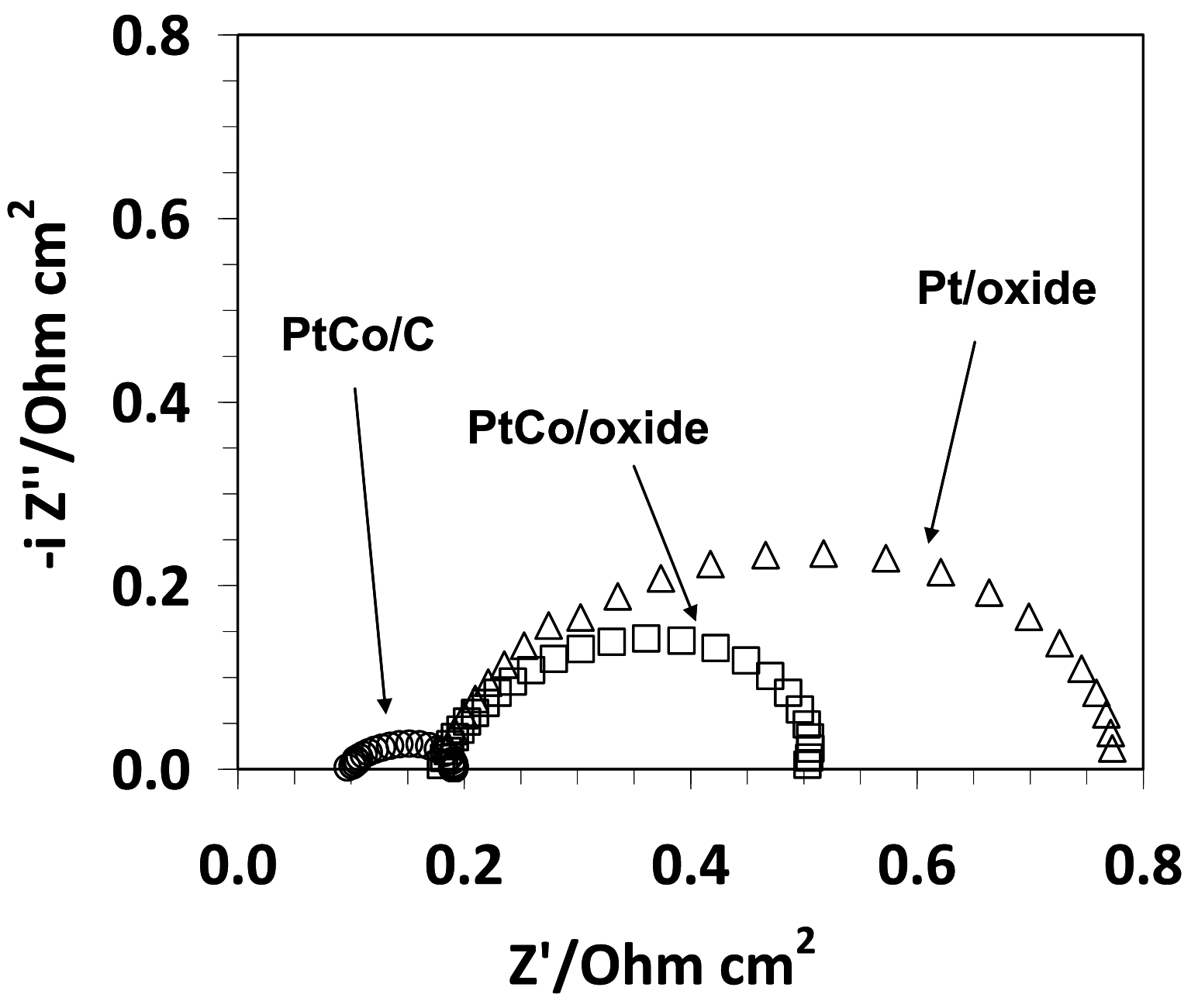

Fig.7 


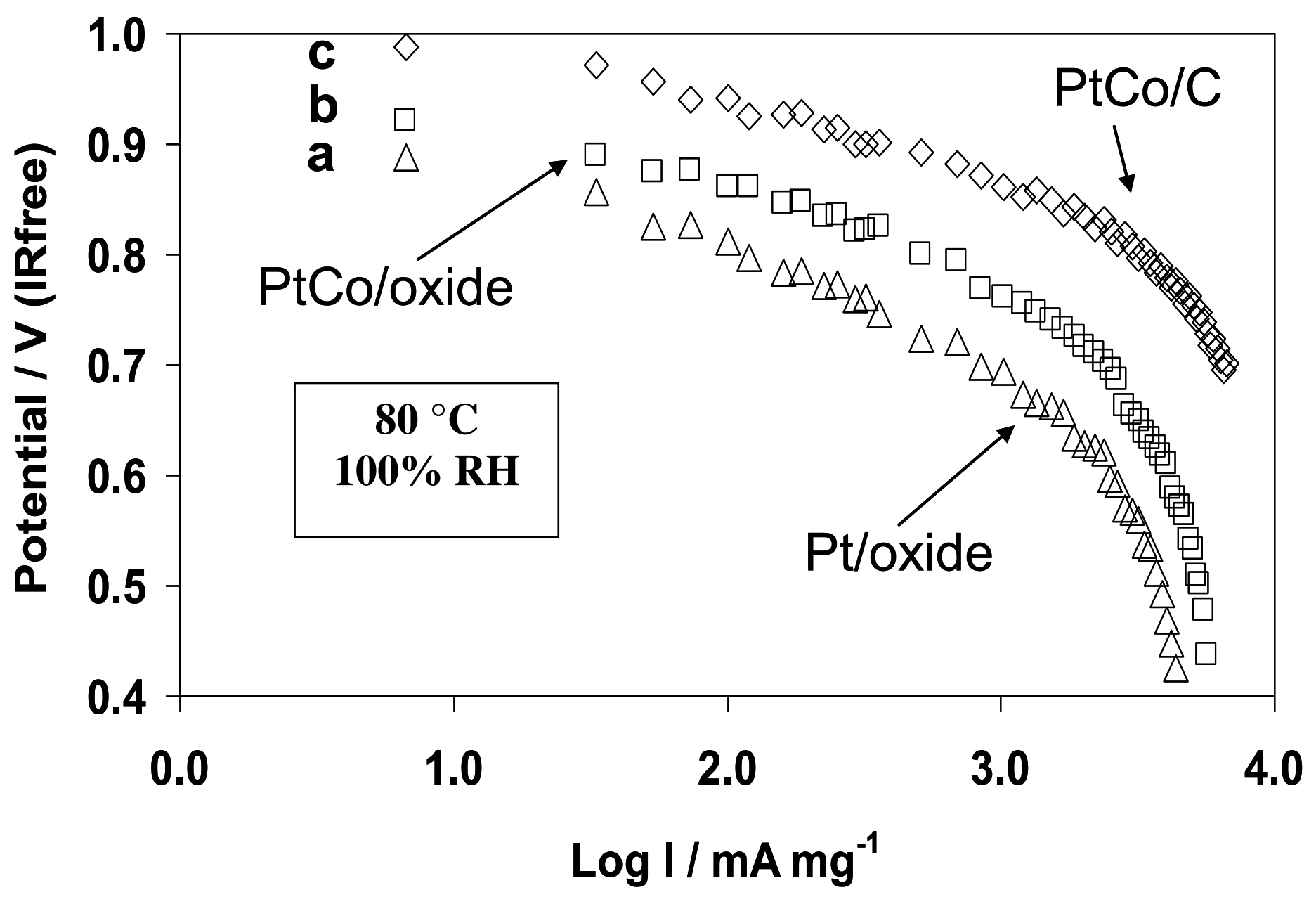

Fig. 8 

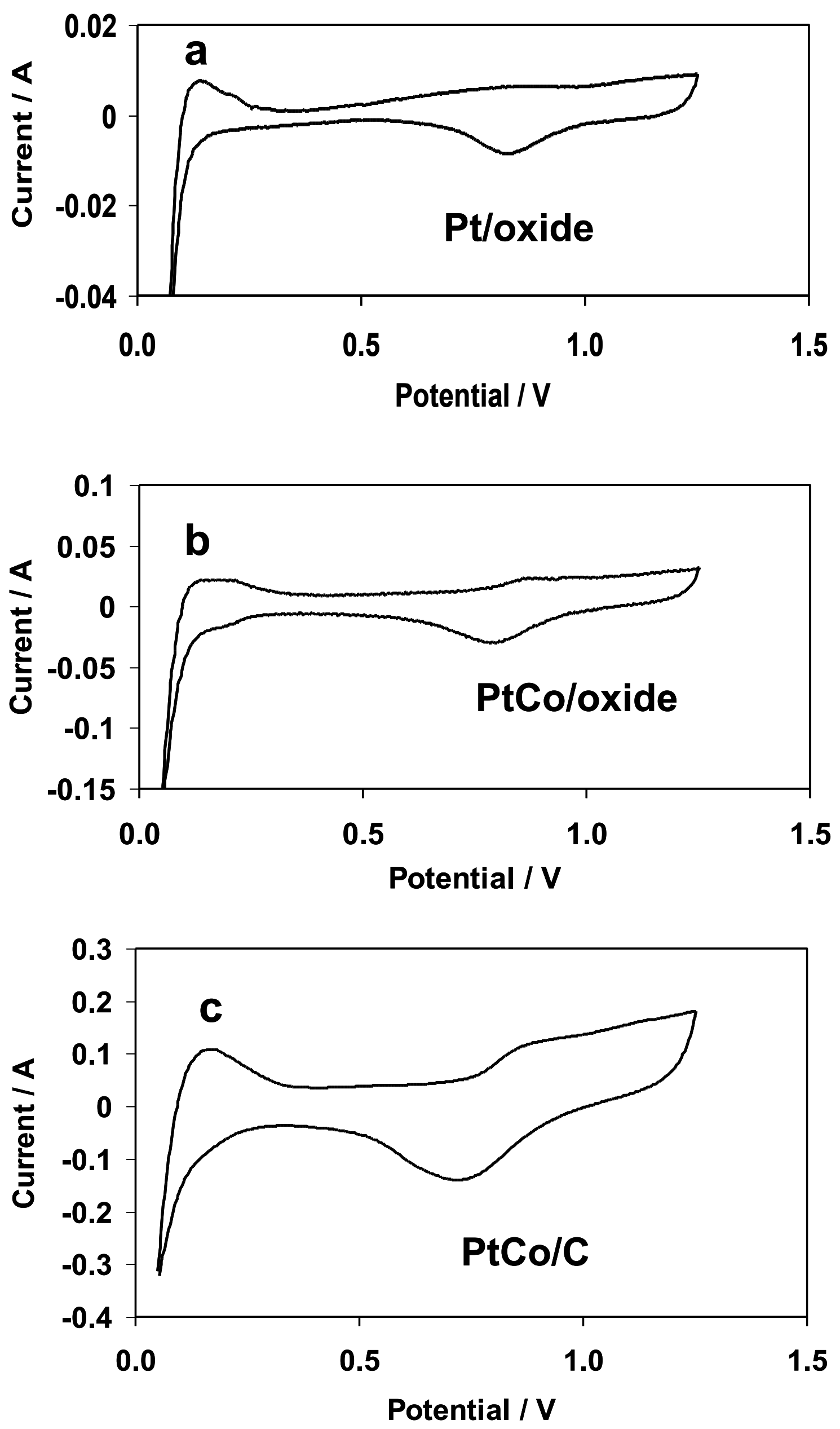

Fig. 9 


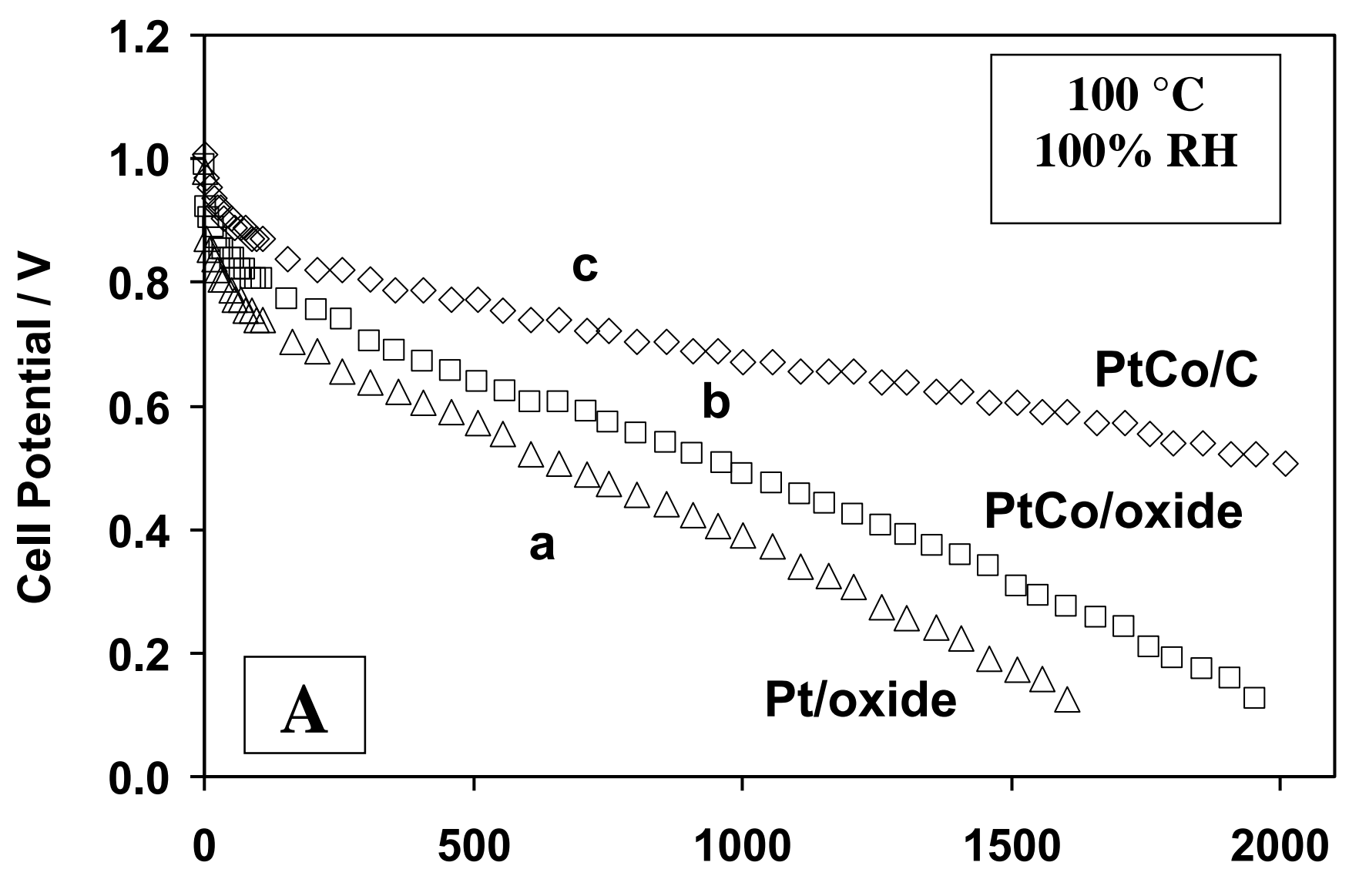

Current density $/ \mathrm{mA} \mathrm{cm}{ }^{-2}$

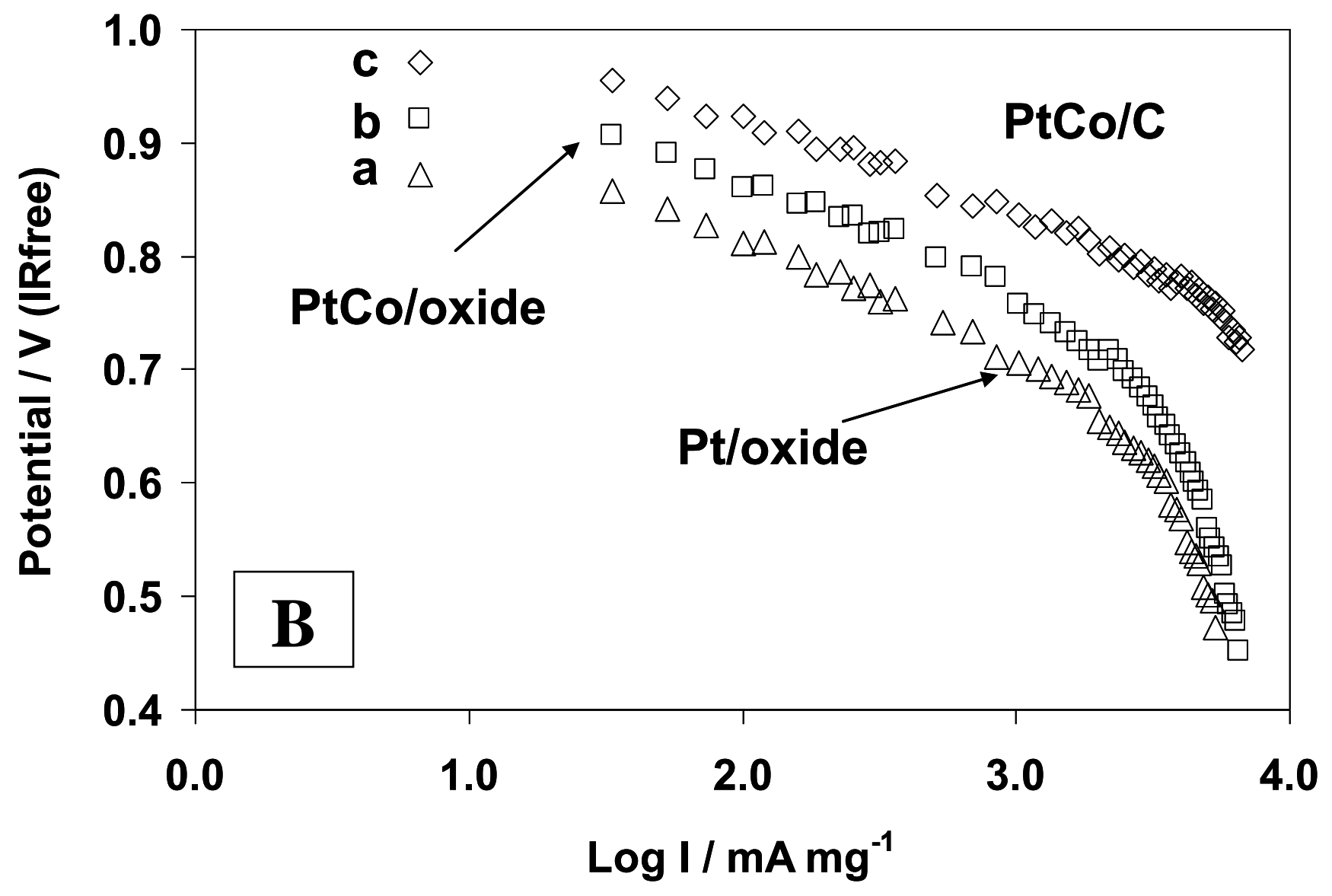

Fig. 10 

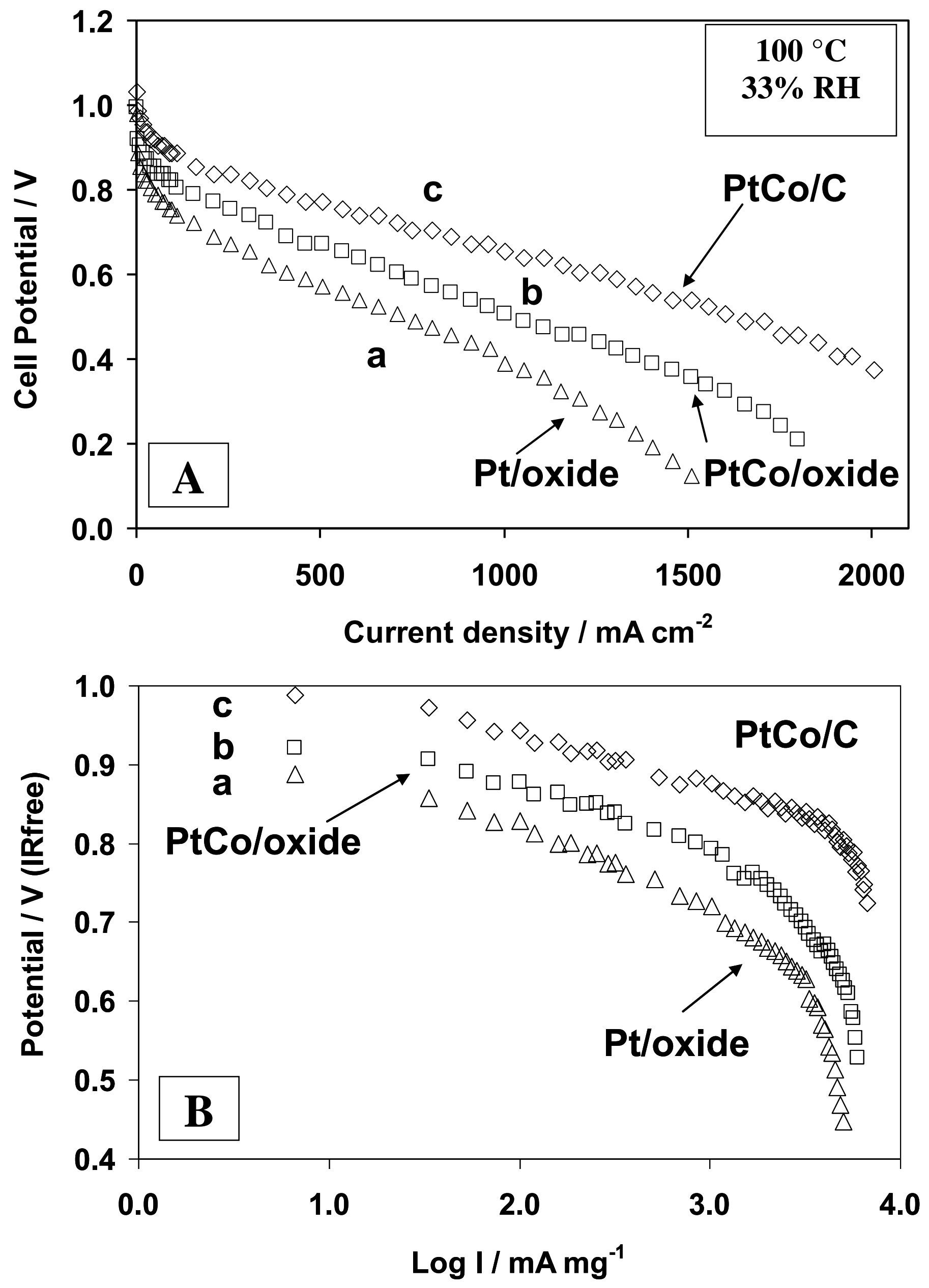

Fig. 11 

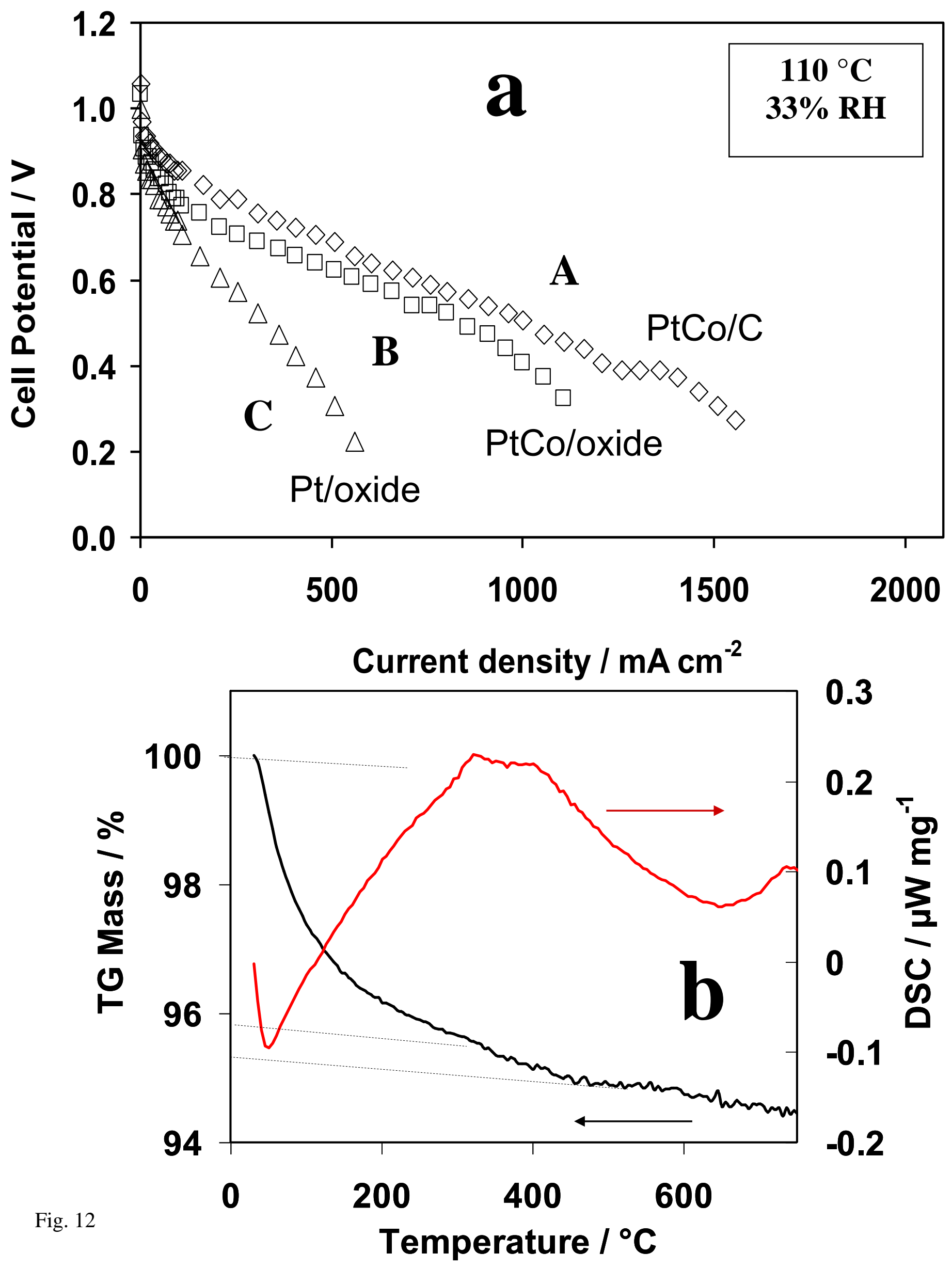

Fig. 12 


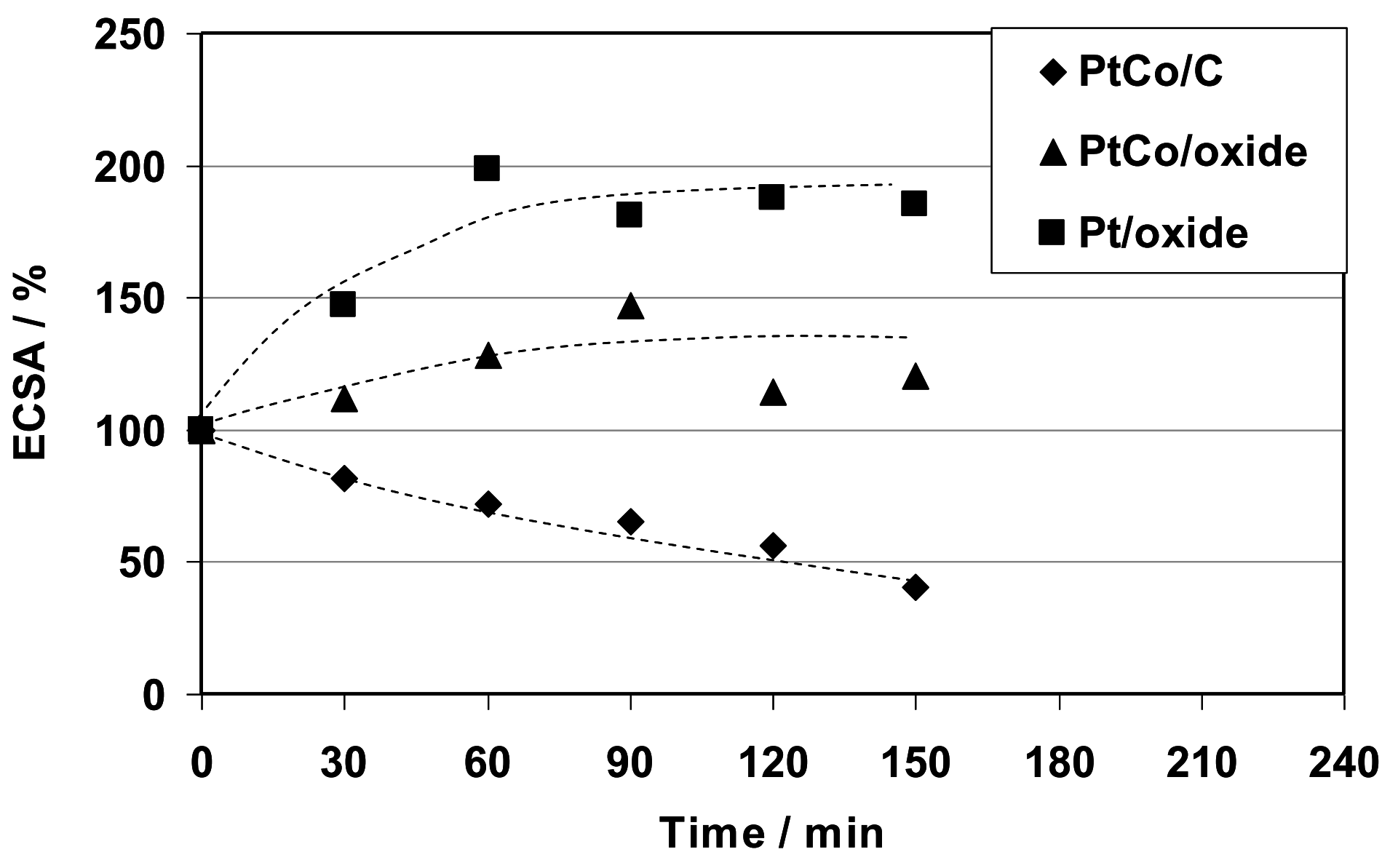

Fig. 13 

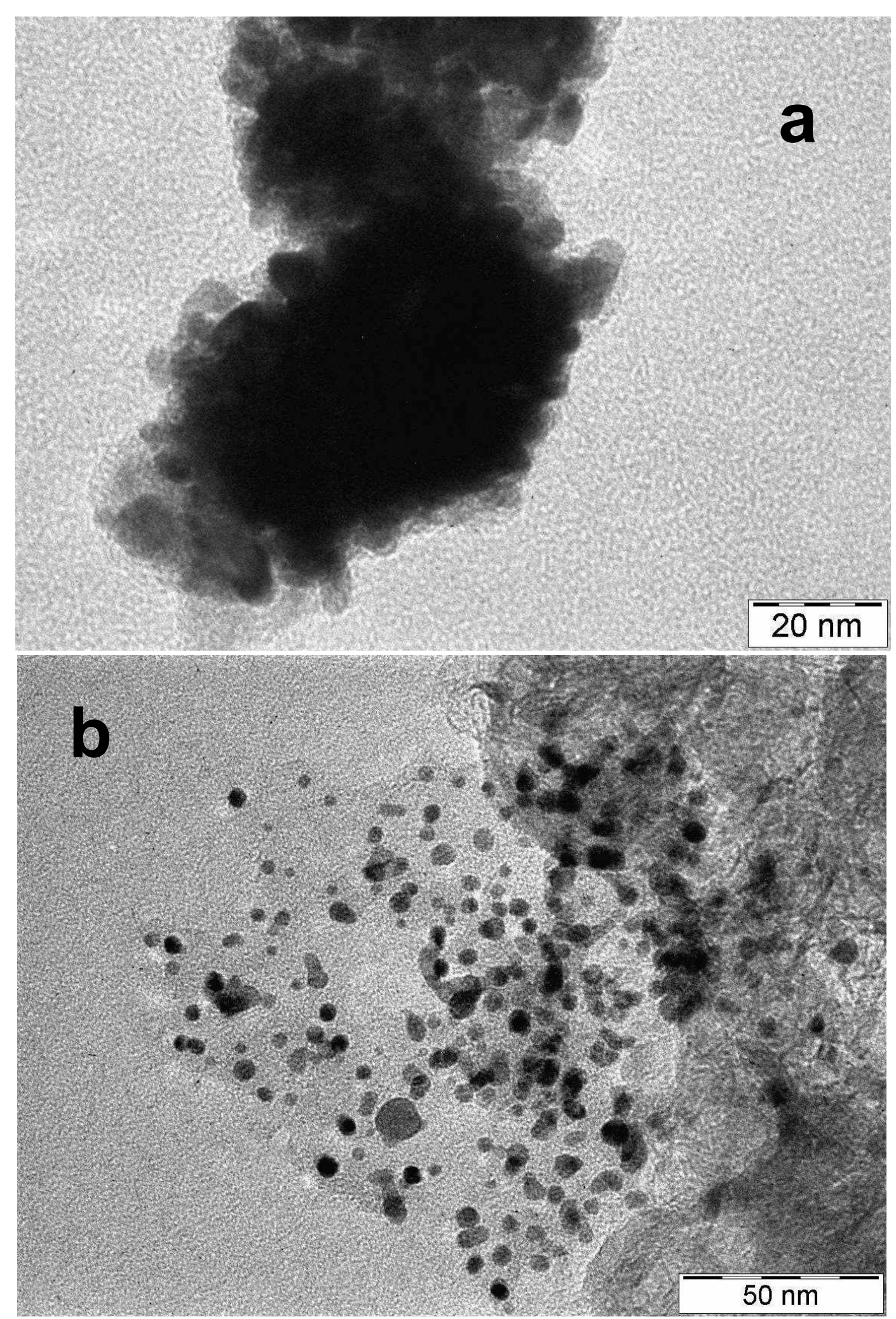

Fig. 14 